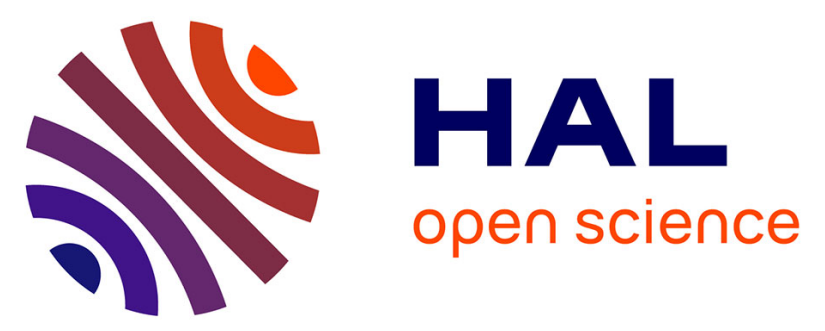

\title{
The signalling axis mediating neuronal apoptosis in response to $\left[\mathrm{Pt}\left(\mathrm{O}, \mathrm{O}^{\prime}\right.\right.$-acac $)(\gamma$-acac $\left.)(\mathrm{DMS})\right]$
}

Antonella Muscella, Nadia Calabriso, Carla Vetrugno, Francesco Paolo Fanizzi, Sandra Angelica De Pascali, Santo Marsigliante

\section{To cite this version:}

Antonella Muscella, Nadia Calabriso, Carla Vetrugno, Francesco Paolo Fanizzi, Sandra Angelica De Pascali, et al.. The signalling axis mediating neuronal apoptosis in response to $\left[\mathrm{Pt}\left(\mathrm{O}, \mathrm{O}^{\prime}\right.\right.$-acac $)(\gamma$ acac)(DMS)]. Biochemical Pharmacology, 2011, 10.1016/j.bcp.2011.03.007 . hal-00693838

\section{HAL Id: hal-00693838 \\ https://hal.science/hal-00693838}

Submitted on 3 May 2012

HAL is a multi-disciplinary open access archive for the deposit and dissemination of scientific research documents, whether they are published or not. The documents may come from teaching and research institutions in France or abroad, or from public or private research centers.
L'archive ouverte pluridisciplinaire $\mathbf{H A L}$, est destinée au dépôt et à la diffusion de documents scientifiques de niveau recherche, publiés ou non, émanant des établissements d'enseignement et de recherche français ou étrangers, des laboratoires publics ou privés. 


\section{Accepted Manuscript}

Title: The signalling axis mediating neuronal apoptosis in response to $\left[\mathrm{Pt}\left(\mathrm{O}, \mathrm{O}^{\prime}\right.\right.$-acac $)(\gamma$-acac $\left.)(\mathrm{DMS})\right]$

Authors: Antonella MUSCELLA, Nadia CALABRISO, Carla VETRUGNO, Francesco Paolo FANIZZI, Sandra Angelica DE PASCALI, Santo MARSIGLIANTE

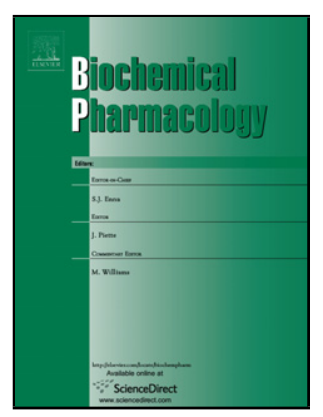

PII: S0006-2952(11)00174-2

DOI: doi:10.1016/j.bcp.2011.03.007

Reference: BCP 10847

To appear in: $\quad B C P$

Received date: $\quad$ 2-1-2011

Revised date: $\quad 9-3-2011$

Accepted date: $\quad$ 10-3-2011

Please cite this article as: MUSCELLA A, CALABRISO N, VETRUGNO C, FANIZZI FP, PASCALI SADE, MARSIGLIANTE S, The signalling axis mediating neuronal apoptosis in response to $\left[\mathrm{Pt}\left(\mathrm{O}, \mathrm{O}^{\prime}\right.\right.$-acac $)(\gamma$-acac $\left.)(\mathrm{DMS})\right]$, Biochemical Pharmacology (2010), doi:10.1016/j.bcp.2011.03.007

This is a PDF file of an unedited manuscript that has been accepted for publication. As a service to our customers we are providing this early version of the manuscript. The manuscript will undergo copyediting, typesetting, and review of the resulting proof before it is published in its final form. Please note that during the production process errors may be discovered which could affect the content, and all legal disclaimers that apply to the journal pertain. 
The signalling axis mediating neuronal apoptosis in response to [Pt(O,O'-acac)(Y-acac)(DMS)]

by: Antonella MUSCELLA ${ }^{1}$, Nadia CALABRISO ${ }^{2}$, Carla VETRUGNO ${ }^{2}$, Francesco Paolo FANIZZI ${ }^{3}$, Sandra Angelica DE PASCALI ${ }^{3}$, \& Santo MARSIGLIANTE ${ }^{2}$

${ }^{1}$ Cell Pathology Lab

${ }^{2}$ Cell Physiology Lab

${ }^{3}$ General and Inorganic Chemistry Lab

all from the

Dipartimento di Scienze e Tecnologie Biologiche e Ambientali (Di.S.Te.B.A.), Universita` del Salento, Lecce, Italy

Running Title:

$\left[\mathrm{Pt}\left(\mathrm{O}, \mathrm{O}^{\prime}\right.\right.$-acac $)(\mathrm{Y}$-acac)$(\mathrm{DMS})]$ provokes apoptosis in SH-SY5Y cells

\section{Correspondence}

relating to this paper can be sent to

Professor S Marsigliante at santo.marsigliante@unisalento.it

Key words: $[\mathrm{Pt}(\mathrm{O}, \mathrm{O}$-acac)(y-acac)(DMS)], apoptosis, PKCs, ROS,

SH-SY5Y, MAPKs

alphabetical list of non-standard abbreviations

DMEM, Dulbecco's modification of Eagle's medium;

DMS, dimethylsulphide;

$E C L$, enhanced chemiluminescence

NBT, nitroblue tetrazolium

PBS, phosphate-buffered saline

PVDF, polyvinylidene difluoride membrane

ROS, reactive oxygen species

SDS, sodium dodecyl sulphate

number of words

Abstract - 250

Introduction - 513

Materials and Methods - 2569

Results - 2244

Discussion - 2056

References - 3539

Legends to Figures - 1511

Total words - 13920 


\begin{abstract}
It was previously shown that $\left[\mathrm{Pt}\left(\mathrm{O}, \mathrm{O}^{\prime}\right.\right.$-acac $)(\mathrm{Y}$-acac $\left.)(\mathrm{DMS})\right]$ induces apoptosis in various cancer cells and exerts antimetastatic responses in vitro. In rats, $\left[\mathrm{Pt}\left(\mathrm{O}, \mathrm{O}^{\prime}-\mathrm{acac}\right)\left(\mathrm{\gamma}^{-}\right.\right.$ acac)(DMS)] reaches the central nervous system in quantities higher than cisplatin causing less excitotoxicity. The aim of the present paper was to investigate whether $\left[\mathrm{Pt}\left(\mathrm{O}, \mathrm{O}^{\prime}\right.\right.$-acac)$(\mathrm{Y}$-acac)(DMS)] is able to exert cytotoxic effects on SH-SY5Y human neuroblastoma cell line, and to study the intracellular transduction mechanisms underlying these effects. Here we have demonstrated that $\left[\mathrm{Pt}\left(\mathrm{O}, \mathrm{O}^{\prime}\right.\right.$-acac $)(\mathrm{\gamma}$-acac $\left.)(\mathrm{DMS})\right]$ was more effective than cisplatin in provoking apoptosis characterized by: (a) mitochondria depolarization, (b) decrease of Bcl-2 expression and increase of BAX expressions with cytosol-to-mitochondria translocation, (c) activation of caspase-7 and -9 and (d) generation of reactive oxygen species (ROS). [ $\mathrm{Pt}\left(\mathrm{O}, \mathrm{O}^{\prime}\right.$-acac) $(\mathrm{Y}$-acac)(DMS)] provoked the activation of the following signalling kinases that were interacting with each other: $P K C-\delta$ and $-\varepsilon$, ERK1/2, p38MAPK, JNK1/2, NF-KB, c-src and FAK. We found that ROS generated by NADPH oxidase was responsible for the $[\mathrm{Pt}(\mathrm{O}, \mathrm{O}$ '-acac) $(\mathrm{Y}$-acac)(DMS)]-mediated PKC- $\delta$ and $-\varepsilon$ activation and consequential phosphorylation of all MAPKs. $\left[\mathrm{Pt}\left(\mathrm{O}, \mathrm{O}^{\prime}\right.\right.$-acac $)(\mathrm{Y}-$ acac)(DMS)]-induced mitochondrial apoptosis was blocked when p38MAPK and JNK1/2 were inhibited, whilst the effects on Bax/Bcl-2 mRNA and protein levels were blocked inhibiting NF-kB. NF-kB nuclear translocation was blocked inhibiting MEK1/2 activity. In addition to the induction of apoptosis $\left[\mathrm{Pt}\left(\mathrm{O}, \mathrm{O}^{\prime}\right.\right.$-acac $)(\mathrm{Y}$-acac)(DMS)] downregulated prosurvival pathway. Survival inhibition started from mitochondrial ROS generation which induced c-src, FAK and Akt activation. In conclusion, our results suggest that $\left[\mathrm{Pt}\left(\mathrm{O}, \mathrm{O}^{\prime}-\right.\right.$ acac)( $\mathrm{Y}$-acac)(DMS)] may be considered a promising compound for the treatment of neuroblastoma. Further studies are warranted to explore in detail the therapeutic potential of this compound.
\end{abstract}




\section{Introduction}

Neuroblastoma is the most common extracranial solid tumour in children [1]. Biologically and clinically, neuroblastomas can be divided into at least two groups: one with favourable biological features (favourable histology, hyperdiploidy) and another with unfavourable features (unfavourable histology, near-diploidy). Favourable neuroblastomas are prone to undergo either differentiation or apoptosis, whereas unfavourable neuroblastomas are frequently metastatic and have poor prognosis.

The current treatment strategy for neuroblastoma uses an aggressive chemotherapy, consisting of a combination of cyclophosphamide, vincristine, tetrahydropyranyl [THP]adriamycin, and cisplatin. This regimen has increased the survival rates of patients with advanced neuroblastoma [2]. However, infusion with cisplatin induces peripheral neuropathy mainly affecting the large myelinated fibers of the nerves secondary to neuronopathy affecting the neurons of dorsal root ganglia [3].

Although tumors with unfavourable biological features may respond to chemotherapy initially, they usually recur and are then resistant to further treatment. Resistance of tumours to treatment might be also associated with defects in, or deregulation of different steps in the apoptotic pathways [4]. Therefore, it is essential to identify new drugs or treatment strategies, which are more efficient and result in fewer toxic side effects.

Much attention has been focused on designing new $\mathrm{Pt}$ compounds with improved pharmacological properties with less toxicity and more favourable therapeutic indices than cisplatin. Recently, a platinum complex containing two acetylacetonate ligands, one $O_{, 0}$ chelate and the other sigma-linked by methionine in the gamma position, and dimethylsulphide (DMS) in the metal coordination sphere has been synthesized [5] and shown to exhibit interesting biological activities [6-9].Differently from cisplatin, for which the activity appears to be associated both with its intracellular accumulation and with the formation of DNA adducts [6,7], the cytotoxicity of this new compound is related to the intracellular accumulation only, showing a low reactivity with nucleobases and a specific reactivity with sulphur ligands, suggesting that the cellular targets could be amino acid residues of proteins. The different action mechanism of the new complex, having different biological targets, with respect to cisplatin, may render it intrinsically able to evoke less chemo-resistance phenomena. In addition to the cytotoxic effects of $\left[\mathrm{Pt}\left(\mathrm{O}, \mathrm{O}^{\prime}-\mathrm{acac}\right)\left(\mathrm{\gamma}^{-}\right.\right.$ acac)(DMS)] in HeLa and MCF-7 cells, we have also demonstrated that $\left[\mathrm{Pt}\left(\mathrm{O}, \mathrm{O}^{\prime}\right.\right.$-acac $)\left(\mathrm{Y}^{-}\right.$ acac)(DMS)] reaches the brain tissue once injected. The brain platinum content after $\left[\mathrm{Pt}\left(\mathrm{O}, \mathrm{O}^{\prime}\right.\right.$-acac $)(\mathrm{Y}$-acac $\left.)(\mathrm{DMS})\right]$ treatment was notably higher than after cisplatin. However, 
compared with cisplatin, $\left[\mathrm{Pt}\left(\mathrm{O}, \mathrm{O}^{\prime}\right.\right.$-acac $)(\mathrm{\gamma}$-acac $\left.)(\mathrm{DMS})\right]$ induces less severe changes on fundamental events of neuroarchitecture development, such as no high apoptotic events, less altered granule cell migration and Purkinje cell dendrite growth, suggesting a low neurotoxicity for normal central nervous system [10]. In light of these results it becomes important to determine whether or not $\left[\mathrm{Pt}\left(\mathrm{O}, \mathrm{O}^{\prime}\right.\right.$-acac $)(\mathrm{Y}$-acac)(DMS)] has cytotoxic effects on brain cancer cells. For this purpose we used the human neuroblastoma SH-SY5Y cells, which are immature neuroblasts [11] that may represent a reliable model for studying the ability of $\left[\mathrm{Pt}\left(\mathrm{O}, \mathrm{O}^{\prime}-\mathrm{acac}\right)(\mathrm{Y}-\mathrm{acac})(\mathrm{DMS})\right]$ to induce cell death and also for elucidate its mechanisms of toxicity. 


\section{Materials and methods}

\subsection{Cell culture}

The human neuroblastoma cell line SH-SY5Y from ICLC (Genova, Italy) are neuron-like cells of human central nervous system origin. SH-SY5Y cells were grown in a 1:1 mixture of Dulbecco's modified Eagle's medium and Ham's F-12 (Celbio, Pero, Milan, Italy) supplemented with $10 \%$ foetal bovine serum, penicillin $(100 \mathrm{U} / \mathrm{mL})$ and streptomycin $(100$ $\mathrm{mg} / \mathrm{mL}$ ), in a humidified atmosphere of $5 \% \mathrm{CO}_{2}$ in air. Cells were grown to $70-80 \%$ confluence and then treated with $\mathrm{Pt}$ compounds at various concentrations and for different incubation periods.

\subsection{Cytotoxicity assay}

Cells at $70-80 \%$ confluency were trypsinised $(0.25 \%$ trypsin with $1 \mathrm{mM}$ EDTA), washed and resuspended in growth medium. $100 \mu \mathrm{L}$ of a cell suspension $\left(10^{5} \mathrm{cells} / \mathrm{mL}\right)$ was added to each well of a 96-well plate. After overnight incubation, cells were treated with specific reagents for different incubation periods.

The conversion of MTT (3-(4,5-dimethylthiazol-2-yl)-2,5-diphenol tetrazolium bromide) by cells was used as an indicator of cell number as previously described [12]. This method measures the reduction of MTT by active mitochondria, which results in a colorimetric change measured at $550 \mathrm{~nm}$ wave length. Experiments were performed to define the linear range of the assay. A good correlation was observed up to 50,000 cells per well (data not shown).

Increasing concentration of heat-killed cells per well (killed by incubating at $70^{\circ} \mathrm{C}$ for 15 min) caused no significant change in the absorbance; thus, this spectrophotometric method was a valid technique for measuring the number of viable cells. All subsequent experiments performed were within the linear range of the assay.

The percentage cell survival was calculated as the absorbance ratio of treated to untreated cells. The data presented are means \pm standard deviation (SD) from eight replicate wells per microtitre plate, repeated four times.

\subsection{Sulforhodamine $B(S R B)$ assay}

The SRB assay was carried out as previously described (Skehan et al., 1990). Briefly, 70 $\mu \mathrm{L} 0.4 \%(\mathrm{w} / \mathrm{v})$ sulforhodamine $\mathrm{B}$ in $1 \%$ acetic acid solution was added to each well and left 
at room temperature for $20 \mathrm{~min}$. SRB was removed and the plates washed 5 times with $1 \%$ acetic acid before air drying. Bound SRB was solubilized with $200 \mu \mathrm{L}$ of $10 \mathrm{mM}$ unbuffered Tris-base solution and plates were left on a plate shaker for at least $10 \mathrm{~min}$. Absorbance was measured in a 96-well plate reader at $492 \mathrm{~nm}$. The test optical density (OD) value was defined as the absorbance of each individual well minus the blank value ('blank' is the mean optical density of the background control wells, $n=8$ ). The percentage survival was calculated as the absorbance ratio of treated to untreated cells. The data presented are means \pm standard deviation (SD) from eight replicate wells per microtitre plate, repeated four times.

\subsection{Trypan blue dye exclusion assay}

The cells were seeded in $60 \mathrm{~mm}$ tissue culture dishes $(100,000 \mathrm{cells} / \mathrm{mL})$. After overnight incubation, the cells were treated with the concentrations of cisplatin or $\left[\mathrm{Pt}\left(\mathrm{O}, \mathrm{O}^{\prime}-\mathrm{acac}\right)(\mathrm{\gamma}\right.$ acac)(DMS)] which were found to produce an IC50 and IC90, for 12 h, 24 h, 48 h, and 72 h. Cell viability was estimated using the trypan blue exclusion assay and light microscopy.

\subsection{Clonogenic survival assay}

Cells were seeded in $100 \mathrm{~mm}$ Petri dishes at low density ( $3 \times 10^{4}$ per dish) and left to adhere for $24 \mathrm{~h}$ in a standard medium. Crescent concentrations of $[\mathrm{Pt}(\mathrm{O}, \mathrm{O}$-acac $)(\mathrm{Y}$ acac)(DMS)] or cisplatin were added; after $2 \mathrm{~h}$ cells were washed, immediately treated with trypsin, resuspended in single-cell suspension, and plated for the determination of macroscopic colony formation. After 15 days of growth, colonies were fixed with a 3:1 mixture of methanol/acetic acid and stained with crystal violet. Only colonies consisting of more than 50 cells were scored. Four separate experiments were performed using duplicate samples.

\subsection{Uptake of JC-1 by mitochondria}

Mitochondrial membrane depolarization was detected by a shift in fluorescence emission of the lipophilic cationic probe 5,5',6,6'-tetrachloro-1,1',3,3'-tetraethylbenzimidazolocarbocyanine iodide (JC-1). JC-1 is able to enter mitochondria selectively, where it exists as a J-aggregate, emitting at $590 \mathrm{~nm}$ (red/yellow) after excitation at $488 \mathrm{~nm}$. Changes in the mitochondrial membrane potential $(\Delta \psi \mathrm{m})$ and subsequent depolarization result in dissociation of the aggregate into the monomeric form of the dye, causing a shift in 
emission to $530 \mathrm{~nm}$ (green), which can be detected.

The uptake of $\mathrm{JC}-1$ and the formation of $\mathrm{J}$-aggregates by cells were monitored by fluorescent spectrophotometer. Inside the mitochondria, the fluorescence emission shifts from green (monomers of JC-1) to red (aggregates). The shifts were detected fluorimetrically (using excitation (EX) $490 \mathrm{~nm}$ and emission (EM) $590 \mathrm{~nm}$ for red, and 525 $\mathrm{nm}$ for green). Mitochondrial depolarization is indicated by a decrease in the red to green fluorescence ratio. Preliminary experiments demonstrated that under these conditions the dye reached near equilibrium distribution and gave a maximal fluorescence response to a fall in $\Delta \psi \mathrm{m}$ induced by the mitochondrial uncoupler carbonylcyanide-m-chloro-phenylhydrazone $(5 \mathrm{mM})$.

\subsection{Preparation of subcellular fraction}

To obtain protein cell extracts, cells were washed twice in ice-cold PBS and harvested in 1 $\mathrm{mL}$ of PBS. The samples were centrifuged for $30 \mathrm{~s}$ at $10,000 \mathrm{xg}$, and cell pellets were resuspended in the following buffer $(\mathrm{mM}): 20$ Tris- $\mathrm{HCl}(\mathrm{pH} 8.0)$ containing $100 \mathrm{NaCl}, 2$ EDTA, $2 \mathrm{Na}_{3} \mathrm{VO}_{4}, 0.2 \%$ Nonidet P-40 and 10\% glycerol, supplemented with a cocktail of protease inhibitors $(1 \mathrm{mg} / \mathrm{mL}$ of each of the proteinase inhibitors aprotinin, leupeptin, soybean trypsin inhibitor, and $1 \mathrm{mM}$ phenylmethylsulphonyl fluoride, all from Sigma, Milan, Italy). After a $10 \mathrm{~min}$ incubation on ice, the cells were passed several times through a 20gauge needle, and then centrifuged at $13,000 \times \mathrm{g}$ for $10 \mathrm{~min}$ at $4^{\circ} \mathrm{C}$. For preparation of subcellular fractions, the cells were ruptured in homogenization buffer $(\mathrm{mM}): 20 \mathrm{Tris}-\mathrm{HCl}$ (pH 7.5) containing 250 sucrose, 2 EDTA, 0.5 EGTA, 0.2 phenylmethylsulphonyl fluoride and the cocktail of protease inhibitors, by Dounce homogenization, and centrifuged immediately at $2,000 \mathrm{xg}$ for $10 \mathrm{~min}$. The supernatant was collected and centrifuged at $100,000 \mathrm{xg}$ for $1 \mathrm{~h}$ to separate cytosolic and membrane fractions. The membrane fraction was subsequently resuspended in extraction buffer $(\mathrm{mM}): 20 \mathrm{Tris}-\mathrm{HCl}(\mathrm{pH} 7.5)$ containing $150 \mathrm{NaCl}, 1$ EDTA, 1 EGTA, 0.2 phenylmethylsulphonyl fluoride and the cocktail of protease inhibitors with $1 \%(\mathrm{v} / \mathrm{v})$ Nonidet P-40.

Nuclei were pelleted by centrifugation at $2,000 \mathrm{xg}$ for $15 \mathrm{~min}$ at $4^{\circ} \mathrm{C}$, and resuspended in high-salt buffer (mM): 20 Tris- $\mathrm{HCl}(\mathrm{pH} 7.9), 420 \mathrm{NaCl}, 10 \mathrm{KCl}, 0.1 \mathrm{Na}_{3} \mathrm{VO}_{4}, 1$ EDTA, 1 EGTA, 20\% glycerol, supplemented with a cocktail of protease inhibitors, and sonicated until no nuclei remained intact. The samples were then centrifuged at $13,000 \mathrm{x}$ for $10 \mathrm{~min}$ at $4^{\circ} \mathrm{C}$, and the resultant supernatant was used as the nuclear extract.

For the preparation of mitochondrial and cytosolic proteins cells were trypsinized and 
washed once with ice-cold phosphate-buffered saline and gently lysed for $30 \mathrm{~s}$ in $80 \mu \mathrm{L}$ ice-cold lysis buffer (250 mM sucrose, 1 mM EDTA, 0.05\% digitonin, $25 \mathrm{mM}$ Tris [pH 6.8], $1 \mathrm{mM}$ dithiothreitol and the cocktail of protease inhibitors). The lysate was centrifuged at $12,000 \times \mathrm{g}$ at $4^{\circ} \mathrm{C}$ for $3 \mathrm{~min}$ to separate the supernatant (mitochondria-free cytosolic extract) and the pellet (mitochondria-containing fraction). Supernatant (40 $\mu \mathrm{g}$ ) and pellet $(40 \mu \mathrm{g})$ were subjected individually to sodium dodecyl sulphate polyacrylamide gel electrophoresis (SDS-PAGE).

The purity of fractions was tested by immunoblotting with anti- $\alpha$ subunit of $\mathrm{Na}^{+} / \mathrm{K}^{+}$-ATPase monoclonal antibody (membrane protein), anti-histone-3/4 polyclonal antibody (nuclear proteins), $\beta$-actin (cytoplasmic protein) or porin (mitochondrial membrane protein). Proteins in the homogenates and cellular fraction were determined using the Bio-Rad (Milan, Italy) protein assay kit 1. Lyophilized BSA was used as a standard.

\subsection{Immunoprecipitation}

Supernatants of homogenates containing $400 \mu \mathrm{g}$ of protein were diluted fourfold with immunoprecipitation buffer ( $\mathrm{pH}$ 7.4) containing $50 \mathrm{mM}$ HEPES, 10\% glycerol, $150 \mathrm{mM}$ $\mathrm{NaCl}, 1 \%$ Triton X-100, $0.5 \% \mathrm{NP}-40$, and $1 \mathrm{mM}$ each of EDTA, EGTA, PMSF, and $\mathrm{Na}_{3} \mathrm{VO}_{4}$. Samples were incubated with 1-2 $\mu \mathrm{g}$ anti-total (phosphorylated and unphosphorylated) JNK3 primary antibody overnight at $4^{\circ} \mathrm{C}$ followed by addition of protein A. After another $2 \mathrm{~h}$ of incubation, samples were centrifuged at $10,000 \times \mathrm{g}$ for $2 \mathrm{~min}$ at $4^{\circ} \mathrm{C}$ and the pellets were washed with immunoprecipitation buffer three times. Bound proteins were eluted by boiling for $5 \mathrm{~min}$ in loading buffer containing $0.125 \mathrm{M}$ Tris- $\mathrm{HCl}(\mathrm{pH} \mathrm{6.8),20 \%} \mathrm{glycerol,} \mathrm{4 \%} \mathrm{sodium}$ dodecyl sulfate (SDS), 10\% mercaptoethanol and $0.002 \%$ bromophenol blue, and then isolated by centrifugation. The supernatants (immunoprecipitates) were used for immunoblotting analysis.

\subsection{Western blot analysis}

Proteins in homogenates and cellular fraction were determined using the Bio-Rad protein assay kit 1. Lyophilized BSA was used as a standard. Total cell proteins or proteins of the distinct subcellular fractions were dissolved in sodium dodecyl sulphate (SDS) sample buffer and separated on 10 or $15 \%$ SDS gels. Separated proteins were transferred electrophoretically onto polyvinylidene difluoride membrane (PVDF) (Amersham International, Piscataway, NJ, USA). Equal protein loading was confirmed by Ponceau S staining. Blots were incubated with specific primary antibodies, and the immune complexes were detected using appropriate peroxidase-conjugated secondary antibodies 
and enhanced chemiluminescent detection reagent ECL (Amersham International). The blots were stripped and used for sequential incubation with control antibodies. Densitometric analysis was carried out on the Western blots using the NIH Image (v1.63) software (National Institutes of Health, Bethesda, MD, USA). The pixel intensity for each region was analysed, the background was subtracted and the protein expressions were normalized to $\beta$-actin loading control for each lane.

\subsection{Reverse transcription and polymerase chain reaction (RT-PCR)}

Total RNA was extracted from SH-SY5Y cells using an SV Total RNA isolation kit and performed according to the manufacturer's protocols (Promega Corporation, USA). The RNA concentration was determined by measuring the absorbance at $260 \mathrm{~nm}$. Samples were then stored at $-20^{\circ} \mathrm{C}$ for subsequent RT-PCR analysis. $1 \mu \mathrm{g}$ of total RNA was used to synthesize a complementary DNA (cDNA) using the RT kit (Promega Corporation, USA). The RT reaction was carried out at $25^{\circ} \mathrm{C}$ for $5 \mathrm{~min}$ followed by $42^{\circ} \mathrm{C}$ for $60 \mathrm{~min}$ and then at $95^{\circ} \mathrm{C}$ for $5 \mathrm{~min}$. The samples were then placed on ice for $5 \mathrm{~min}$ and stored at $-20^{\circ} \mathrm{C}$ for PCR amplification. PCR was performed using a BioRad iQ iCycler Detection System (BioRad Laboratories, Ltd) with SYBR green fluorophore (SyberGreen Supermix; Biorad Laboratories, USA) in the presence of $2 \mu \mathrm{M}$ of specific primers for Bax, $\mathrm{Bcl}-2$ and $\beta$-actin. A melt curve analysis was performed following every run to ensure a single amplified product for every reaction. For each gene, relative expression was determined using the $2^{-\Delta \Delta C T}$ method and normalized to $\beta$-actin expression [14].

\subsection{Apoptosis analysis}

For 4,6-diammine-2-phenylindol (DAPI) staining, cells treated with cisplatin or $[\mathrm{Pt}(\mathrm{O}, \mathrm{O}$ acac)( $\mathrm{Y}$-acac)(DMS)] were fixed with $3 \%$ formalin and stained with $1 \mathrm{mg} / \mathrm{mL}$ DAPI in PBS for $10 \mathrm{~min}$. Cells were mounted on glass slides, covered, and analysed using fluorescence microscopy. For statistical analysis of each experiment, 5-10 fields (magnification X 400) were counted (between 400 and 700 cells in total). The mean \pm SD was calculated and displayed as bar graph.

\subsection{Intracellular reactive oxygen species (ROS) formation}

ROS generation was detected by nitroblue tetrazolium (NBT) assay as previously described [15]. Data are expressed as \% of control untreated cells. 


\subsection{Anion superoxide $\left(\mathrm{O}^{2-}\right)$ production}

$\mathrm{O}^{2}$ is the main free radical produced in mitochondria and was measured in SH-SY5Y cells using the cell-permeable probe MitoSOX Red as previously described [15].

The fluorescence intensity was measured with a JASCO FP 750 fluorimeter (Jasco Corporation, Japan). Excitation monochromators were set at $488 \mathrm{~nm}$, with a chopper interval of $0.5 \mathrm{~s}$, and the emission monochromator was set at $580 \mathrm{~nm}$.

\subsection{Design and preparation of small interfering RNA (siRNA)}

siRNAs were prepared by an in vitro transcription method, according to the manufacturer's protocol (Promega, Madison, WI, USA). Initially, four siRNA target sites specific to human protein kinase $C(P K C)-\varepsilon$ mRNA, four siRNA target sites specific to human PKC- $\delta$ mRNA, four PKC- $\alpha$ mRNA and five siRNA to p65, as determined by blast analysis, were chosen. For each siRNA, sense and antisense templates were designed based on each target sequence and partial T7 promoter sequence. All template oligonucleotides were chemically synthesized and PAGE purified. In vitro transcription, annealing and purification of siRNA duplexes were performed using the protocol supplied with the T7 RiboMAX Express RNAi System (Promega Corporation). Briefly, approximately $2 \mu \mathrm{g}$ of each singlestranded transcription template was first annealed with the T7 promoter and filled in by Klenow DNA polymerase to form double-stranded transcription templates. For preparation of each siRNA duplex, transcription reactions were first performed with separated antisense and sense templates using the T7 RNA polymerase provided with the kit, and then annealed to form siRNA duplexes. Then, the siRNA duplex was treated with DNase and RNase to remove the extra nucleotides of transcribed siRNA to meet the structural 3'UUU overhang and 5' phosphate requirement.

\subsection{SiRNA transfection}

The cells (50-70\% confluence) were transfected with siRNA duplexes using the protocol supplied with the CodeBreaker siRNA transfection reagent (Promega Corporation). Briefly, the transfection reagent was first diluted into DMEM/Ham's F-12 medium without serum and antibiotics for about $15 \mathrm{~min}$, and then the sense and non-sense siRNA (siRNA-NS) duplex were added to the medium to form a lipid-siRNA complex. Following additional 15 min incubation, transfection was initiated by adding the lipid-siRNA complex to six-well plates. The final concentrations of siRNAs were $10 \mathrm{nM}$. Immunoblottings were performed 24 and $48 \mathrm{~h}$ post-transfection to determine the efficiency of siRNA incorporation in cells and to measure the protein expressions. Quantitative analysis of protein expression, as 
measured by intensity of immunoreactivity in siRNA-transfected cells, revealed a higher reduction in PKC- $\alpha$, PKC- $\varepsilon$, PKC- $\delta$ and $p 65$ expression.

\subsection{Statistical analysis}

Experimental points represent means \pm standard deviation (SD) of 3-6 replicates. Statistical analysis was carried out using the ANOVA. When indicated, post hoc tests (Bonferroni/Dunn) were also performed. A $\mathrm{P}$ value less than 0.05 was considered to achieve statistical significance.

\subsection{Reagents}

$\left[\mathrm{Pt}\left(\mathrm{O}, \mathrm{O}^{\prime}\right.\right.$-acac $)(\gamma$-acac $\left.)(\mathrm{DMS})\right]$ was prepared according to previously reported procedures [5].

Caspase-7, -9 and -3, Bax, Bid, poly(ADP-ribose) polymerase (PARP), phospho-specific pAkt (Ser473) and total (phosphorylated and unphosphorylated) Akt, phospho-specific pERK1/2 and total (phosphorylated and unphosphorylated) ERK1/2, phospho-specific pp38MAPK (Thr180/Tyr182) and total (phosphorylated and unphosphorylated) p38MAPK antibodies, phospho-specific p-FAK (Tyr397) and total (phosphorylated and unphosphorylated) FAK antibodies, phospho-specific p-src (Tyr416) and total (phosphorylated and unphosphorylated) src antibodies were obtained from Cell Signaling Technology (Celbio, Milan, Italy).

PKC isoforms antibodies, phospho-specific p-JNK1/2 (Thr183/Tyr185) total (phosphorylated and unphosphorylated) JNK1/2 antibodies and Bcl-2 antibody were obtained from Sigma (Milan, Italy). Phospho-specific p-JNK1/2/3, (Tyr185, Tyr185, Tyr223) were obtained from Diagnostic Brokers Associated (DBA), Milano, Italy.

Anti-porin (or anti-voltage-dependent anion selective channel 1, VDAC1), anti-p65 antibody, anti total (phosphorylated and unphosphorylated) JNK3, anti-histone-3/4 antibodies, goat anti-rabbit IgG conjugated with peroxidase, as well as control antibodies, were obtained from Santa Cruz Biotechnology (Santa Cruz, CA, USA).

The inhibitor of NF-KB quinazoline (QNZ), the MAPK inhibitors PD98059, SP600125 and SB203580, the inhibitor of C-src PP1, the PKC- $\varepsilon$ translocation inhibitor peptide $\varepsilon V 1$ were obtained from Calbiochem (Darmstadt, Germany). The inhibitors of NADPH oxidase, diphenyleneiodonium (DPI) and apocynin, nitroblue tetrazolium (NBT), MitoSOX Red and all the inorganic salts were obtained from Sigma (Milan, Italy). 
Protein assay kit 1 was obtained from Bio-Rad (Milan, Italy), proteinase $\mathrm{K}$ and RNase $\mathrm{A}$ from Sigma (Milan, Italy). SpectrAA-880Z spectrometer from Varian Inc. (Vacuum Technologies, San Diego, CA, USA), Wizard genomic DNA purification kit from Promega (Madison, WI, USA), polyvinylidene difluoride membrane and chemiluminescent detection reagent ECL from Amersham International (Piscataway, NJ, USA), glass coverslips from Bradford Scientific (Epping, NH, USA), DMSO from Sigma (St Louis, MO, USA), Histovitrex mounting medium from Carlo Erba (Milan, Italy) and JC-1 Kit from Cell Technology (Mountain View, CA, USA). 


\section{RESULTS}

\subsection{Cytotoxicity of [Pt(O,O'-acac)(Y-acac)(DMS)]}

The cytotoxicity data shown here were obtained by MTT metabolic assay and confirmed by SRB assay to rule out potential effects of $\left[\mathrm{Pt}\left(\mathrm{O}, \mathrm{O}^{\prime}\right.\right.$-acac $)(\mathrm{\gamma}$-acac)(DMS $\left.)\right]$ on mitochondrial enzymes. Indeed, comparable results were obtained when cell number was directly determined by cell counting (data not shown); consequently, we used MTT assay in the combined experiments reported.

Exposure of SH-SY5Y cells to cisplatin and to $\left[\mathrm{Pt}\left(\mathrm{O}, \mathrm{O}^{\prime}\right.\right.$-acac $)(\mathrm{Y}$-acac $\left.)(\mathrm{DMS})\right]$ at concentrations ranging from $1 \mu \mathrm{M}$ to $200 \mu \mathrm{M}$ resulted in a dose-dependent inhibition of cell survival (Fig. 1). In subsequent experiments we chose to use $10 \mu \mathrm{M}\left[\mathrm{Pt}\left(\mathrm{O}, \mathrm{O}^{\prime}\right.\right.$-acac $)\left(\mathrm{Y}^{-}\right.$ acac)(DMS)] because, after passing 12 hours of incubation, it is the minimum concentration to which we have the maximum cytotoxic effect (Fig 1). $\left[\mathrm{Pt}\left(\mathrm{O}, \mathrm{O}^{\prime}\right.\right.$-acac) $\left(\gamma^{-}\right.$ acac)(DMS)] showed cytotoxicity approximately 10 -fold greater than that observed for cisplatin ( $\mathrm{IC}_{50}$ at $24 \mathrm{~h}$ were $4.2 \pm 0.2 \mu \mathrm{M}$ for $\left[\mathrm{Pt}\left(\mathrm{O}, \mathrm{O}^{\prime}\right.\right.$-acac) $(\mathrm{Y}$-acac)(DMS)] and $50.8 \pm 1.2$ $\mu \mathrm{M}$ for cisplatin, $\mathrm{n}=4$ ) (see table in Fig. 2). In Fig. $2 A$ it can be seen that about $50 \%$ of cells died after only $6 \mathrm{~h}$ of treatment with $10 \mu \mathrm{M}\left[\mathrm{Pt}\left(\mathrm{O}, \mathrm{O}^{\prime}-\mathrm{acac}\right)(\mathrm{\gamma}\right.$-acac)(DMS)], while it was necessary to incubate for about $12 \mathrm{~h}$ to get the same effect using $100 \mu \mathrm{M}$ cisplatin.

Results of the clonogenic assay are shown in Fig. 2D: it can be seen that $10 \mu \mathrm{M}\left[\mathrm{Pt}\left(\mathrm{O}, \mathrm{O}^{\prime}-\right.\right.$ acac)(y-acac)(DMS)] was significantly more cytotoxic than $100 \mu \mathrm{M}$ cisplatin.

\section{2. [Pt(O,O'-acac)(Y-acac)(DMS)] causes caspases proteolysis and increases pro- apoptotic protein Bax and decreases anti-apoptotic protein Bcl-2}

To compare the pathways leading to the induction of cell death in response to cisplatin and [Pt(O,O'-acac)(y-acac)(DMS)], the cleavage patterns of caspase-3, 7 and -9 , and PARP were analysed by western blotting. PARP has been shown to be one of the first proteins specifically cleaved by caspase-3 and -7 during apoptosis [16]. Therefore, PARP cleavage was examined by western blotting of proteins obtained from isolated nuclei. As shown in Fig. 3, both $100 \mu \mathrm{M}$ cisplatin and $10 \mu \mathrm{M}\left[\mathrm{Pt}\left(\mathrm{O}, \mathrm{O}^{\prime}\right.\right.$-acac $)(\mathrm{Y}$-acac)(DMS)] significantly increased the amounts of cleaved PARP, thus confirming the early signs of apoptosis process. PARP degradation was already evident after $1 \mathrm{~h}$ of [Pt(O,O'-acac)(y-acac)(DMS)] treatment, while cisplatin provoked the fragmentation of PARP after $12 \mathrm{~h}$ of treatment. Sequential incubation of the blot with anti-actin antibody confirmed that the amount of protein loaded was the same. Both $\left[\mathrm{Pt}\left(\mathrm{O}, \mathrm{O}^{\prime}\right.\right.$-acac $)(\mathrm{Y}$-acac)(DMS)] and cisplatin caused the proteolysis of procaspase-7; this cleavage occurred faster in the $\left[\mathrm{Pt}\left(\mathrm{O}, \mathrm{O}^{\prime}-\mathrm{acac}\right)(\mathrm{Y}\right.$ - 
acac)(DMS)]-treated cells (Fig. 3). Finally, we examined caspase-9, known to be the predominant activator of caspase-7, although some alternative pathways have also been described [17]. We found that the earliest generation of the activated caspase-9 heterodimers, after drug administration, preceded the activation of caspase-7 in both cisplatin- and $\left[\mathrm{Pt}\left(\mathrm{O}, \mathrm{O}^{\prime}\right.\right.$-acac $)(\mathrm{Y}$-acac)(DMS)]-treated cells (Fig. 3). Whilst cisplatin also provoked the proteolysis of caspase-3, $\left[\mathrm{Pt}\left(\mathrm{O}, \mathrm{O}^{\prime}\right.\right.$-acac $)(\mathrm{Y}$-acac $\left.)(\mathrm{DMS})\right]$-treated cells did not show such activation, at least up to $24 \mathrm{~h}$ of treatment (Fig. 3). We determined the effects of $\left[\mathrm{Pt}\left(\mathrm{O}, \mathrm{O}^{\prime}\right.\right.$-acac $)(\mathrm{Y}$-acac $\left.)(\mathrm{DMS})\right]$ on pro- and anti-apoptotic Bcl-2 family proteins. [Pt(O,O'acac)(Y-acac)(DMS)] increased Bax and decreased Bcl-2 levels (Fig. 3). We also assessed the effects of $10 \mu \mathrm{M}\left[\mathrm{Pt}\left(\mathrm{O}, \mathrm{O}^{\prime}\right.\right.$-acac)( $\mathrm{\gamma}$-acac)(DMS)] or $100 \mu \mathrm{M}$ cisplatin on the expression of Bid, Bax and Bcl-2 proteins by western blot analysis in whole cells. Neither cisplatin nor $\left[\mathrm{Pt}\left(\mathrm{O}, \mathrm{O}^{\prime}-\mathrm{acac}\right)(\mathrm{Y}\right.$-acac)(DMS)] altered Bid expression (data not shown); conversely, Bcl-2 level was decreased by [Pt(O,O'-acac)(Y-acac)(DMS)] treatment (Fig. 3). Bax level increased slightly in cisplatin-treated cell and much more in $\left[\mathrm{Pt}\left(\mathrm{O}, \mathrm{O}^{\prime}\right.\right.$-acac $)\left(\gamma^{-}\right.$ acac)(DMS)]-treated cells (Fig. 3). Furthermore, [Pt(O,O'-acac)(Y-acac)(DMS)] also provoked Bax translocation from the cytosol to mitochondria, a phenomenon that preceded the decrement of $\Delta \Psi \mathrm{m}$.

\subsection{Effect of $\left[\mathrm{Pt}\left(\mathrm{O}, \mathrm{O}^{\prime}\right.\right.$-acac $)(\mathrm{Y}$-acac $\left.)(\mathrm{DMS})\right]$ on $\Delta \boldsymbol{\Psi}_{\mathrm{m}}$}

A decrement in $\Delta \Psi_{\mathrm{m}}$ accompanies early apoptosis in many systems. $\Delta \Psi_{\mathrm{m}}$ was monitored by fluorescence of the cationic lipophilic dye JC-1 in cells treated with $10 \mu \mathrm{M}\left[\mathrm{Pt}\left(\mathrm{O}, \mathrm{O}^{\prime}-\right.\right.$ acac)( $\mathrm{Y}$-acac)(DMS)]. JC-1 possesses the ability to form multimers known as J-aggregates after accumulation in mitochondria with high membrane potential. In addition to Jaggregates, JC-1 can form monomers in mitochondria with low membrane potential. Mitochondrial membrane depolarization was detected fluorimetrically by a shift in fluorescence emission of $\mathrm{JC}-1$; after addition of $\left[\mathrm{Pt}\left(\mathrm{O}, \mathrm{O}^{\prime}\right.\right.$-acac $)(\mathrm{\gamma}$-acac)(DMS $\left.)\right], \Delta \Psi_{\mathrm{m}}$ decreased slowly and gradually starting from $15 \mathrm{~min}$, as determined by mean aggregate fluorescence of JC-1 (Fig. 4A). The depolarizing agent carbonylcyanide-m-chlorophenylhydrazone (5 mM), incubated for $10 \mathrm{~min}$, was used as a positive control.

\section{4. $\left[\mathrm{Pt}\left(\mathrm{O}, \mathrm{O}^{\prime}\right.\right.$-acac $)(\mathrm{Y}$-acac)(DMS)] causes release of mitochondrial cytochrome $\mathrm{c}$}

Release of cytochrome $\mathrm{c}$ is known to be associated with the induction of apoptosis. In order to evaluate the effect of $\left[\mathrm{Pt}\left(\mathrm{O}, \mathrm{O}^{\prime}\right.\right.$-acac $)(\mathrm{Y}$-acac) $(\mathrm{DMS})]$ on cytochrome c release from mitochondria, we treated the cells with $10 \mu \mathrm{M}\left[\mathrm{Pt}\left(\mathrm{O}, \mathrm{O}^{\prime}\right.\right.$-acac)( $\mathrm{Y}$-acac)(DMS)] for different time. Mitochondrial and cytosolic fractions were then separated as described in materials 
and methods. Cytosolic cytochrome c levels were measured by immunoblot analysis. Cytosol from untreated cells did not show detectable cytochrome c protein (data not shown). In contrast, mitochondrial cytochrome $c$ decreased significantly (densitometric analysis (D.A.): ANOVA $\mathrm{p}<0.01)$ with $\left[\mathrm{Pt}\left(\mathrm{O}, \mathrm{O}^{\prime}\right.\right.$-acac $)(\mathrm{y}$-acac)(DMS)] (Fig. 4B). Porin in mitochondrial extracts was used as a control (Fig. 4B).

In addition, in mitochondrial fractions of [Pt(O,O'-acac)(y-acac)(DMS)]-treated cells, Bax expression increased as the expression of an antiapoptotic factor, Bcl-2, declined (D.A.: ANOVA $p<0.01$ for both Bax and Bcl-2 protein levels, Fig. 4B).

\section{5. [Pt(O,O'-acac)( $\mathrm{Y}$-acac)(DMS)]-induces MAPKs phosphorylation}

We evaluated the effects of $\left[\mathrm{Pt}\left(\mathrm{O}, \mathrm{O}^{\prime}\right.\right.$-acac $)(\mathrm{y}$-acac)(DMS)] on the activation state of extracellular-signal-regulated protein kinase (ERK1/2), c-jun N-terminal kinase (JNK1/2 and JNK3), and P38MAPK, inasmuch as they are involved in many cellular functions, ranging from proliferation to differentiation and apoptosis. Western blot analysis using specific antibodies to phosphorylated ERK1/2, p38MAPK, and JNK1/2 revealed that $\left[\mathrm{Pt}\left(\mathrm{O}, \mathrm{O}^{\prime}\right.\right.$-acac $)(\mathrm{Y}$-acac)(DMS)] provoked their phosphorylation in different time-dependent manner (D.A.: ANOVA p $<0.01$ for all, Fig. 4C), without affecting the overall level, as detected by antibodies recognising both phosphorylated and un-phosphorylated forms (Fig. 4C). In order to evaluate the effects of [Pt(O,O'-acac)(Y-acac)(DMS)] on the activation state of JNK3, we immunoprecipitated total JNK3 using a specific anti-JNK3 monoclonal antibody. The immunoprecipitated protein was used for immunoblotting analysis with an antibody recognising the phosphorylated forms of JNK1/2/3 (Tyr185, Tyr185, Tyr223). As shown in Fig. 4C, no activation of JNK3 protein was observed (D.A.: ANOVA p >0.05).

By using an antibody which recognises the dually phosphorylated (Thr180 and Tyr182) p38MAPK we found that it was activated by $[\mathrm{Pt}(\mathrm{O}, \mathrm{O}$ '-acac $)(\mathrm{Y}$-acac)(DMS $)]$ as early as 5 min of treatment. Persistent activation is observed until $6 \mathrm{~h}$ of treatment although the levels of activation are somewhat lower than that seen initially (Fig. 4C). The p38MAPK inhibitor SB203580 (Fig. 5A) significantly reduced [Pt(O,O'-acac)(Y-acac)(DMS)]-induced cytotoxicity (Fig. 5A).

[Pt $\left(\mathrm{O}, \mathrm{O}^{\prime}\right.$-acac)(Y-acac)(DMS)] also provoked JNK1/2 activation after $15 \mathrm{~min}$, reaching its maximal phosphorylation at $1 \mathrm{~h}$. The JNK1/2 phosphorylation decreased after $3 \mathrm{~h}$. Using an antibody recognising both phosphorylated and un-phosphorylated JNK1/2 we found that the overall level was not affected (Fig. 4C). The JNK1/2 inhibitor SP600125 significantly attenuates $\left[\mathrm{Pt}\left(\mathrm{O}, \mathrm{O}^{\prime}\right.\right.$-acac)(Y-acac)(DMS)]-induced cells death (Fig. 5B).

$\left[\mathrm{Pt}\left(\mathrm{O}, \mathrm{O}^{\prime}-\mathrm{acac}\right)(\mathrm{Y}\right.$-acac $\left.)(\mathrm{DMS})\right]$ induced a rapid phosphorylation of ERK1/2, with a threshold 
increase at $5 \mathrm{~min}$ and a maximal effect at about $30 \mathrm{~min}$; then, such phosphorylation declined and was undetectable after $12 \mathrm{~h}$ (Fig. 4C). Inhibition of ERK1/2 upstream kinase MEK1/2 by PD98059 significantly reduced [Pt(O,O'-acac)(Y-acac)(DMS)]-induced cytotoxicity (Fig. 6C). PD98059 blocked ERK1/2 activation and decreased the number of apoptotic cells. The exposure of cells to PD98059 alone for $1 \mathrm{~h}$ inhibited ERK1/2 phosphorylation (D.A.: ANOVA $p<0.01$ ) and had no effect on apoptosis (Fig. $6 \mathrm{C}$ ).

The production of active caspase-9 was also significantly reduced by all MAPK inhibitors used: SP600125, SB203580 (D.A.: ANOVA p<0.01 Fig. 5A and B), and PD98059 (D.A.: ANOVA $p<0.01$ Fig. $6 C)$, indicating that MAPK activities are essential for $\left[\mathrm{Pt}\left(\mathrm{O}, \mathrm{O}^{\prime}\right.\right.$-acac $)\left(\gamma^{-}\right.$ acac)(DMS)]-induced apoptosis.

Further, we examined whether $\left[\mathrm{Pt}\left(\mathrm{O}, \mathrm{O}^{\prime}\right.\right.$-acac $)(\mathrm{Y}$-acac)(DMS)]-induced MAPKs activation was required for the mechanism that allows the dissipation of mitochondrial membrane potential and the release of cytochrome $\mathrm{c}$.

SB203580 and SP600125 reversed the $[\mathrm{Pt}(\mathrm{O}, \mathrm{O}$ '-acac)(Y-acac)(DMS)]-induced release of cytochrome $\mathrm{c}$, the $\mathrm{Bcl}-2$ decrease and the translocation of Bax from the cytosol to the outer mitochondrial membrane (D.A.: ANOVA $p<0.01$, Fig. $5 A$ and $B$ ). This indicates that p38MAPK and JNK1/2 activities are essential for [Pt(O,O'-acac)(Y-acac)(DMS)]-induced mitochondrial apoptosis.

\section{6. $\left[\mathrm{Pt}\left(\mathrm{O}, \mathrm{O}^{\prime}\right.\right.$-acac)( $\mathrm{Y}$-acac)(DMS)] induces NF-KB activation}

By real-time RT-PCR we found that $\left[\mathrm{Pt}\left(\mathrm{O}, \mathrm{O}^{\prime}\right.\right.$-acac)( $\mathrm{Y}$-acac)(DMS)] up-regulated Bax mRNA and down-regulated Bcl-2 mRNA, in a time-dependent manner (D.A.: ANOVA $p<0.01$, Fig. $6 \mathrm{~A})$.

In SH-SY5Y and in other cell types, NF-kB, a dimer of p50 and p65 subunits, is held in the cytoplasm in an inactive form bound to inhibitors such as IKB- $\alpha$. Phosphorylation of IKB- $\alpha$ targets it for ubiquitination and destruction, thus releasing NF-kB which is then translocated to the nucleus. To determine whether [Pt(O,O'-acac)(Y-acac)(DMS)] activated $\mathrm{NF}-\mathrm{KB}$, we prepared cytosolic and nuclear fractions from cells incubated with $10 \mu \mathrm{M}$ $[\mathrm{Pt}(\mathrm{O}, \mathrm{O}$ '-acac $)(\mathrm{Y}-\mathrm{acac})(\mathrm{DMS})]$. Degradation of IkB- $\alpha$ and translocation of NF-kB were studied by Western blotting using an anti-IKB- $\alpha$ or anti-NF-KB (p65) antibodies, respectively.

As shown in Fig. 6B, $[\mathrm{Pt}(\mathrm{O}, \mathrm{O}$-acac)(Y-acac)(DMS)] rapidly (within $5 \mathrm{~min}$ ) stimulated IKB- $\alpha$ degradation and NF-KB (p65) nuclear translocation (D.A.: ANOVA $p<0.01)$.

As shown in Fig. 6D [Pt(O,O'-acac)(Y-acac)(DMS)] affected Bax/Bcl-2 protein levels and such effects were inhibited by pretreatment with $10 \mu \mathrm{M}$ QNZ (quinazoline: 6-Amino-4-(4- 
phenoxyphenylethylamine), an inhibitor of the NF-kB transcriptional activation (D.A.: Student's $t$ test $p<0.01$ ). To confirm the role of NF-kB p65 subunit, experiments were performed using cells transfected with either a siRNA oligonucleotide sequence specific for p65 or with scramble siRNA. This procedure knocked down p65 expression in sheared cells relative to cells transfected with scramble siRNA (D.A.: Student's t test $p<0.01$, Fig. $6 \mathrm{D})$, and blocked Bax upregulation and Bcl-2 downregulation in $\left[\mathrm{Pt}\left(\mathrm{O}, \mathrm{O}^{\prime}\right.\right.$-acac $)\left(\mathrm{Y}^{-}\right.$ acac)(DMS)]-treated SH-SY5Y cells (D.A.: Student's t test $p<0.01$ ). Scramble control siRNA had no effect (D.A.: Student's t test p>0.05, Fig. 6D).

Since it has been reported that activation of MAPKs is upstream of NF-kB [18], we determined their role in the modulation of Bax/Bcl-2 protein expression due to $\left[\mathrm{Pt}\left(\mathrm{O}, \mathrm{O}^{\prime}-\right.\right.$ acac)( $\left.\left(\gamma^{-a c a c}\right)(D M S)\right]$. Thus, activation of NF-kB was assessed following $\left[\mathrm{Pt}\left(\mathrm{O}, \mathrm{O}^{\prime}-\mathrm{acac}\right)\left(\mathrm{\gamma}^{-}\right.\right.$ acac)(DMS)] administration in the presence of inhibitors for MEK1/2 (PD98059), JNK1/2 (SP600125) and p38MAPK (SB203580). [Pt(O,O'-acac)(y-acac)(DMS)]-stimulated NF$\mathrm{KB}(\mathrm{p} 65)$ translocation was significantly inhibited by PD98059 (D.A.: Student's $t$ test $\mathrm{p}<0.01$, Fig. 6D), but not by SB203580 and SP600125 (data not shown). PD98059 also reversed the effects of $\left[\mathrm{Pt}\left(\mathrm{O}, \mathrm{O}^{\prime}-\mathrm{acac}\right)(\mathrm{Y}\right.$-acac $\left.)(\mathrm{DMS})\right]$ on both $\mathrm{Bax}$ and $\mathrm{Bcl}-2$ espressions (D.A.: Student's t test $p<0.01$, Fig. 6D).

\subsection{The mechanism of $\left[\mathrm{Pt}\left(\mathrm{O}, \mathrm{O}^{\prime}\right.\right.$-acac)(Y-acac)(DMS)]-induced MAPKs phosphorylation}

Role of PKC. SH-SY5Y cells express at least five isoforms of PKCs: $-\alpha,-\beta,-\delta,-\varepsilon$ and $-\zeta$ [19]. Inasmuch as activated PKCs translocate from the cytosol to the cellular membranes, we analysed, by immunoblottings, the distribution of PKCs in cells treated with $10 \mu \mathrm{M}$ $\left[\mathrm{Pt}\left(\mathrm{O}, \mathrm{O}^{\prime}\right.\right.$-acac)$(\mathrm{Y}$-acac)(DMS)] for different incubation times (0-30 min). As shown in Fig. 7A, a cytosol-to-membrane translocations of PKC- $\alpha, P K C-\delta$ and PKC- $\varepsilon$ were observed. Then, we used molecular (PKC- $\alpha$-siRNA, PKC- $\varepsilon$-siRNA and PKC- $\delta$-siRNA) and pharmacological (the PKC- $\alpha / \beta$ inhibitor Görelin, the PKC- $\delta$ inhibitor rottlerin and the PKC- $\varepsilon$ translocation inhibitor peptide $\varepsilon \vee 1$, an octapeptide that selectively inhibits the translocation

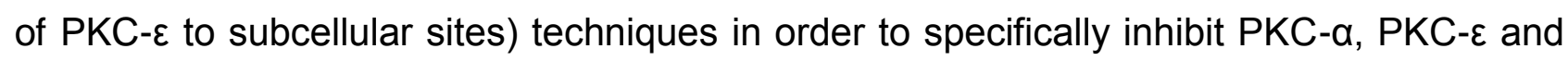
PKC- $\delta$ and establish their role in MAPKs control. Preliminary experiments by Western blotting demonstrated that PKC- $\alpha$-siRNA, PKC- $\varepsilon$-siRNA and PKC- $\delta$-siRNA were able to decrease PKC- $\alpha, P K C-\varepsilon$ and PKC- $\delta$ expressions and that nonspecific siRNA (siRNA-NS) had no silencing effect (Fig. 7B). The inhibition of PKC- $\delta$ blocked $\left[\mathrm{Pt}\left(\mathrm{O}, \mathrm{O}^{\prime}\right.\right.$-acac $)(\mathrm{Y}-$ acac)(DMS)]-induced JNK1/2 and p38MAPK phosphorylation (D.A.: Student's t test $\mathrm{p}<0.01$, Fig. 7C). Likewise, PKC- $\varepsilon$-siRNA (10 nM) inhibited [Pt(O,O'-acac)(y-acac)(DMS)]- 
induced ERK1/2 phosphorylation (D.A.: Student's t test $p<0.01$, Fig. 7C) and p65 cytosolto-nucleus translocation; in addition, PKC- $\varepsilon$-siRNA reversed the NF-KB-mediated downregulation of Bcl-2 and up-regulation of Bax expression (D.A.: Student's t test $p<0.01$, Fig. 7D). This result was confirmed by using $\varepsilon \vee 1$ (data not shown).

\subsection{Role of ROS}

There is also evidence that oxidants activate MAPKs signalling pathways [20]. By using the NBT assay we found that $\left[\mathrm{Pt}\left(\mathrm{O}, \mathrm{O}^{\prime}-\mathrm{acac}\right)(\mathrm{Y}\right.$-acac $\left.)(\mathrm{DMS})\right]$ increased the level of ROS in a time-dependent manner with ROS generation significantly different respect to control $(p<0.005)$ as soon as $2.5 \mathrm{~min}$ (Fig. $8 \mathrm{~A})$. Such ROS production was decreased by diphenyleneiodonium (DPI), an inhibitor of the $\mathrm{NAD}(\mathrm{P}) \mathrm{H}$ oxidase (Fig. 8A). Since another important sources of intracellular ROS is mitochondrium, we studied the specific production of mitochondrial $\mathrm{O}^{-2}$ by MitoSOX red. We found that $\left[\mathrm{Pt}\left(\mathrm{O}, \mathrm{O}^{\prime}-\mathrm{acac}\right)\left(\mathrm{Y}^{-}\right.\right.$ acac)(DMS)] increased the mitochondrial synthesis of $\mathrm{O}^{-2}$ in a time-dependent manner (Fig. 8B), and that such effect was blocked by the antioxidant apocynin $(10 \mu \mathrm{M})$ a natural organic compound structurally related to vanillin, also known as acetovanillone (Fig. 8B). Finally, DPI completely inhibited the $\left[\mathrm{Pt}\left(\mathrm{O}, \mathrm{O}^{\prime}\right.\right.$-acac)( $(\gamma$-acac)(DMS)]-induced PKC- $\delta$ and PKC- $\varepsilon$ translocations (D.A.: Student's $t$ test $p<0.01$, Fig. $8 \mathrm{C}$ ) and MAPKs phosphorylations (D.A.: Student's $t$ test $p<0.01$, Fig. $8 D$ ), thus suggesting the involvement of $N A D(P) H$ oxidase in these processes.

\section{9. $\left[\mathrm{Pt}\left(\mathrm{O}, \mathrm{O}^{\prime}\right.\right.$-acac)(Y-acac)(DMS)] activates Akt}

It is known that PI3K/Akt pathway is involved in the survival of several cell types [21-24]. Western blotting with an antibody that specifically detect phosphorylated Akt (p-Akt) showed that $[\mathrm{Pt}(\mathrm{O}, \mathrm{O}$-acac $)(\mathrm{Y}$-acac $)(\mathrm{DMS})]$ caused a time-dependent increase of the phosphorylation up to 15 minutes; then, the level of p-Akt, but not of total Akt, was suppressed (D.A.: ANOVA $p<0.01$, Fig. 4C)

To determine the relevance of this pathway for apoptosis resistance, we used LY294002, a PI3K inhibitor. LY294002 completely abrogated both endogenous and $\left[\mathrm{Pt}\left(\mathrm{O}, \mathrm{O}^{\prime}\right.\right.$-acac $)\left(\mathrm{Y}^{-}\right.$ acac)(DMS)]-induced p-Akt (data not shown). Inhibition of Akt led to enhanced sensitivity to $\left[\mathrm{Pt}\left(\mathrm{O}, \mathrm{O}^{\prime}\right.\right.$-acac)(Y-acac)(DMS)]-induced apoptosis, as observed by MTT assay and caspase-7 activation, in the first hour of treatment (Fig. 9A and D). In addition, we found that cell treatment with LY294002 alone induced apoptosis (Fig. 9A). These findings suggested that $[\mathrm{Pt}(\mathrm{O}, \mathrm{O}$-acac $)(\mathrm{Y}$-acac)(DMS)] was able to inactivate an important prosurvival pathway in these cells. 
Because MAPKs activation is required for [Pt(O,O'-acac)( $(y-a c a c)(D M S)]$-induced apoptosis, we analyzed whether inhibition of the antiapoptotic pathways had an effect on these kinases. Indeed, LY294002 enhanced [Pt(O,O'-acac)(Y-acac)(DMS)]-induced activation of p38MAPK and JNK1/2 (D.A.: ANOVA $p<0.01$, Fig. 9D), but not of ERK1/2 (data not shown).

\subsection{Mitochondrial ROS induced c-src and Fak activation}

Because it is known that ROS may induce src phosphorylation [25,26], we performed Western analysis using antibodies recognizing total (phosphorylated and unphosphorylated) and phosphorylated src (p-src). As shown in Fig. 9B, $\left[\mathrm{Pt}\left(\mathrm{O}, \mathrm{O}^{\prime}-\mathrm{acac}\right)\left(\mathrm{\gamma}^{-}\right.\right.$ acac)(DMS)] induced src phosphorylation, which resulted greatly decreased in the presence of apocynin (D.A.: ANOVA $p<0.01$, Fig. 9 C), thus suggesting the involvement of mitochondrial ROS (mROS).

$\mathrm{PP} 1$, a src inhibitor, blocked the phosphorylation of src induced by $\left[\mathrm{Pt}\left(\mathrm{O}, \mathrm{O}^{\prime}-\mathrm{acac}\right)\left(\mathrm{\gamma}^{-}\right.\right.$ acac)(DMS)], and reversed the effect of [Pt(O,O'-acac)(y-acac)(DMS)] on Akt phosphorylation (D.A.: ANOVA $p<0.01$, Fig. $9 \mathrm{C}$ ). It is known that src can phosphorylate FAK leading to its activation. We observed that $\left[\mathrm{Pt}\left(\mathrm{O}, \mathrm{O}^{\prime}\right.\right.$-acac $)(\mathrm{\gamma}$-acac $\left.)(\mathrm{DMS})\right]$ provoked FAK phosphorylation and it sequential (after $1 \mathrm{~h}$ treatment) cleavage to a $77 \mathrm{KDa}$ product (D.A.: ANOVA p $<0.01$, Fig. 9B). FAK cleavage occurred early in apoptosis and correlated temporally with caspase-7 cleavage (Fig. 3 ). 


\section{DISCUSSION}

Despite substantial improvements in childhood cancer survival, drug resistance remains problematic for several tumour types, neuroblastoma included. The urgent need to access novel agents to treat drug-resistant disease should be expedited by gaining a fuller understanding of the signalling events that couple drug-induced damage signals to the engagement of apoptosis. In recent years our group is studying a complex of Pt (II) containing two acetylacetonate (acac) ligands and dimethylsulphide (DMS) in the metal coordination sphere that has shown interesting biological activities [5]. $\left[\mathrm{Pt}\left(\mathrm{O}, \mathrm{O}^{\prime}\right.\right.$-acac $)\left(\gamma^{-}\right.$ acac)(DMS)] not only was able to induce apoptosis in endometrial cancer cells (HeLa), with activity up to about 100 times higher than that of cisplatin, but also showed high cytotoxicity in cisplatin-resistant MCF-7 breast cancer cells. Differently from cisplatin, for which the activity appears to be associated both with its intracellular accumulation and with the formation of DNA adducts [6,7], the cytotoxicity of this new compound is related to the intracellular accumulation only, showing a low reactivity with nucleobases and a specific reactivity with sulphur ligands, suggesting that the cellular targets could be amino acid residues of proteins. The different mechanism of action of the new complex, having biological targets, different from those of cisplatin, may render it intrinsically able to evoke less chemo-resistance. Theoretically, this compound could produce, in addition, a broader spectrum of application, since we have assessed its ability to exert also specific antimetastatic responses in vitro [9]. Interestingly, [Pt(O,O'-acac)(Y-acac)(DMS)] passes the blood-brain barrier and reaches the central nervous system in doses much higher than cisplatin [10]. Nevertheless, $\left[\mathrm{Pt}\left(\mathrm{O}, \mathrm{O}^{\prime}\right.\right.$-acac $)(\mathrm{\gamma}$-acac)(DMS)] displayed a low cytotoxic effect on normal tissue, certainly less important than the neurotoxicity caused by cisplatin. This is important because neurotoxicity is one of the cisplatin side effects. As a consequence, the question arises whether $\left[\mathrm{Pt}\left(\mathrm{O}, \mathrm{O}^{\prime}\right.\right.$-acac $)(\mathrm{Y}$-acac $\left.)(\mathrm{DMS})\right]$ is toxic for tumour cells derived from brain. We show here that $\left[\mathrm{Pt}\left(\mathrm{O}, \mathrm{O}^{\prime}-\mathrm{acac}\right)(\mathrm{Y}\right.$-acac $\left.)(\mathrm{DMS})\right]$ is toxic to neuroblastoma cells, with effects significantly greater than those caused by cisplatin (Figs 1 and 2). In SHSY5Y cells $[\mathrm{Pt}(\mathrm{O}, \mathrm{O}$-acac)( $\mathrm{Y}$-acac)(DMS)] provoked the characteristic features of apoptosis including activation of caspase-9 and caspase-7, cleavage of PARP, as well as nuclear condensation/ fragmentation (Figs 2 and 3 )

As shown previously, cisplatin induces Bax translocation from cytosol to mitochondria, where it inserts into the outer mitochondrial membrane [8]. This same mechanism occurs with $\left[\mathrm{Pt}\left(\mathrm{O}, \mathrm{O}^{\prime}\right.\right.$-acac $)(\mathrm{Y}$-acac $\left.)(\mathrm{DMS})\right]$, but with a different kinetic. $\left[\mathrm{Pt}\left(\mathrm{O}, \mathrm{O}^{\prime}\right.\right.$-acac $)(\mathrm{Y}$ acac)(DMS)] more rapidly dissipates mitochondrial membrane potential $\left(\Delta \Psi_{\mathrm{m}}\right)$ in whole 
cells. Dissipation of $\Delta \Psi_{\mathrm{m}}$ is accompanied by the release of cytochrome c into the cytoplasm, activation of caspase- 9 and subsequent activation of the executioner caspases to orchestrate apoptosis. Apoptosis associated to mitochondrial events induced by [Pt $\left(\mathrm{O}, \mathrm{O}^{\prime}\right.$-acac) $(\mathrm{Y}$-acac)(DMS)] have been shown is facilitated by altered expression and mitochondrial localization of apoptotic regulators, such as Bcl-2 down-regulation and mitochondrial translocation of Bax and t-Bid [7] (Fig. 4). The crucial role of Bax/Bcl-2 in mitochondrial permeability and $\Delta \Psi_{\mathrm{m}}$ loss has been well established $[27,28]$. The downregulation of the Bcl-2 protein level observed in many different models of apoptosis, neuronal and non-neuronal, decreases its capacity to form heterodimers with the related pro-apoptotic protein Bax, or to link with specific molecules, thus of $\mathrm{Bcl}-2$, thus preventing its anti-apoptotic activity [29-31]. This decrease in Bcl-2 protein level also occurs in $\mathrm{SH}$ SY5Y cells incubated with $[\mathrm{Pt}(\mathrm{O}, \mathrm{O}$-acac $)(\mathrm{Y}$-acac)(DMS)] together with the up-regulation of Bax protein level and its translocation to mitochondria. No effect was observed, however, on Bid, revealing that this pathway is not involved in $\left[\mathrm{Pt}\left(\mathrm{O}, \mathrm{O}^{\prime}\right.\right.$-acac $)(\mathrm{y}$-acac)(DMS $\left.)\right]-$ induced mitochondrial alterations. Since activated MAPKs are components of the apoptotic program [32], we studied their behavior in cells treated with [Pt(O,O'-acac)(y-acac)(DMS)]; in addition it has been shown previously that p38MAPK and JNK1/2 contributes to SHSY5Y cell apoptosis [31]. Actually, $\left[\mathrm{Pt}\left(\mathrm{O}, \mathrm{O}^{\prime}\right.\right.$-acac $)(\mathrm{Y}$-acac)(DMS)] strongly caused the phosphorylation of ERK1/2, p38MAPK, JNK1/2 but not JNK3 (Fig. 4). Activation of p38MAPK and JNK1/2 was related to apoptosis induction since their inhibition prevented cytochrome $c$ release and caspase- 9 and -7 activation (Fig. 5). Similarly, p38MAPK phosphorylation is required for the apoptosis in leukemia cells [33], in U-937 promonocytic cells treated with cadmium chloride [34] and in mouse cortical neuronal cells treated with calyculin A, a selective inhibitor of Ser/Thr phosphatase I and IIA [35]. The JNK1/2 pathway has been implicated in signalling events in many forms of neuronal apoptosis [36]. In response to a variety of extracellular stimuli, JNK1/2 phosphorylates and regulates the activity of members of the Bcl-2 family (Bcl-2, Bcl-xL, Bim and Bad) [37,38] and modulates $\mathrm{Bcl}-2$ and Bax protein expression $[37,39,40]$.

Phosphorylation of Bax by both JNK1/2 and p38MAPK has been reported to initiate its activation and mitochondrial translocation [41], whilst phosphorylation of $\mathrm{Bcl}-2$ by p38MAPK enhances its degradation by proteasome-dependent pathway [42]. The proteolytic cleavage of $\mathrm{Bcl}-2$ may be also caspase $3 / 7$ dependent. If this was the case, it would have had resulted in the appearance of a $23 \mathrm{kDa} \mathrm{Bcl}-2$ fragment. In this study, the time course of caspase- 7 activation is not time related to $\mathrm{Bcl}-2$ degradation. We exclude the hypothesis that proteolytic cleavage of $\mathrm{Bcl}-2$ is caspase dependent. Another 
explanation for $\mathrm{Bcl}-2$ decrement after $\left[\mathrm{Pt}\left(\mathrm{O}, \mathrm{O}^{\prime}-\mathrm{acac}\right)(\mathrm{\gamma}\right.$-acac)(DMS $)$ ] exposure is a $\mathrm{Bcl}-2$ transcriptional regulation; the increase in the amount of Bax may be also due to upregulation at the transcriptional level.

NF-KB plays a role in regulating the expression levels of $\mathrm{Bcl}-2$ proteins $[43,44]$. Depending on the specific role of NF-KB in apoptosis, it may regulate the expression of either proapoptotic or antiapoptotic Bcl-2 proteins [45]. However, since in SH-SY5Y and in some neuronal cell types NF-KB is more-commonly associated with pro-apoptotic functions $[44,46]$, and because NF-KB activation plays a pro-apoptotic role also in $\left[\mathrm{Pt}(\mathrm{O}, \mathrm{O}\right.$ '-acac $)\left(\mathrm{Y}^{-}\right.$ acac)(DMS)]-incubated SH-SY5Y cells, we examined the ability of NF-KB to up-regulate $\mathrm{Bax}$ and/or to down-regulate $\mathrm{Bcl}-2$. Indeed, NF-kB activated by $\left[\mathrm{Pt}\left(\mathrm{O}, \mathrm{O}^{\prime}\right.\right.$-acac $)\left(\mathrm{Y}^{-}\right.$ acac)(DMS)] down-regulated and up-regulated the expression of $\mathrm{Bcl}-2$ and $\mathrm{Bax}$, respectively (Fig. 6). These effects may be, at least partially, responsible for the death induction in SH-SY5Y cells. Since NF-KB is differentially regulated by the level of phosphorylation of the MAPKs $[47,48]$, we investigated whether inhibition of MAPKs is able of curtailing NF-KB activity and subsequently modifing Bcl-2 proteins expression. Among the MAPKs activated by $\left[\operatorname{Pt}\left(O, O^{\prime}-a c a c\right)(y-a c a c)(D M S)\right]$, we showed that $E R K 1 / 2$ is upstream of NF-KB, because its inhibition blocked IK-Ba degradation and NF-KB activation (Fig. 6). In addition, inhibition of ERK1/2 and of its activator, PKC- $\varepsilon$, significantly reduced also $\left[\mathrm{Pt}\left(\mathrm{O}, \mathrm{O}^{\prime}\right.\right.$-acac)(Y-acac)(DMS)]-induced cytotoxicity and reversed the effects of NF-KB on Bcl-2 and Bax expression (Fig. 7D). Accordingly, ERK1/2 activation can contribute to the apoptosis induced by $\mathrm{H}_{2} \mathrm{O}_{2}$ in $\mathrm{SH}-\mathrm{SY} 5 \mathrm{Y}$ [49], in oligodendrocytes [50] and in neurons [51].

Agents activating MAPKs and NF-KB also induce an overproduction of ROS, suggesting that a cross-talk may occur between these pathways. The exact site of action of MAPKs along the pathway leading to NF-KB activation, as well as the mechanisms by which $\left[\mathrm{Pt}\left(\mathrm{O}, \mathrm{O}^{\prime}\right.\right.$-acac $)(\mathrm{Y}$-acac)(DMS)] provokes ROS production, likely trough the activation of nicotinamide adenine-dinucleotide(phosphate) $[\mathrm{NAD}(\mathrm{P}) \mathrm{H}]$ oxidase, are still elusive. In MCF-7 cells, $\left[\mathrm{Pt}\left(\mathrm{O}, \mathrm{O}^{\prime}-\mathrm{acac}\right)(\mathrm{\gamma}\right.$-acac)(DMS)] increases the synthesis of ROS through both activation of $\mathrm{NAD}(\mathrm{P}) \mathrm{H}$ oxidase and mitochondrial pathways [9], as often observed in the early stages of apoptosis [52]. Here, inhibition of $\mathrm{NAD}(\mathrm{P}) \mathrm{H}$ oxidase blocks activation of MAPKs, suggesting ROS generation upstream to MAPK activation in SH-SY5Y cells (Fig. 8). We here determined the position of MAPKs in the signalling pathway from ROS production to NF-KB activation and apoptosis. ERK1/2 activation is linked to PKC- $\varepsilon$, since siRNA-PKC- $\varepsilon$ blocked ERK1/2 activation and reversed p65-subunit nuclear translocation (Fig. 7D). PKC- $\varepsilon$ can be involved in ERK1/2 activation at several levels of the classical 
MAPK cascade [53], including the direct interaction with MEK [54]. In HeLa cells, [Pt(O,O'acac)( $\mathrm{Y}$-acac)(DMS)] induced ERK1/2 activation through PKCs [6]. Also, PKCs pathways regulate cell death by both cisplatin [55] and [Pt(O,O'-acac)( $\gamma$-acac)(DMS)] [6]. In thyroid $\mathrm{PC} \mathrm{Cl} 3$ cell line, PKC- $\varepsilon$ has a role in the apoptosis-signalling pathways caused by many stimuli [56]; in these cells PKC- $\varepsilon$ also mediates the apoptotic effects of cisplatin through p38MAPK activity [8]. In the present work, p38MAPK and JNK1/2 activations were mediated by PKC- $\delta$ (Fig. 7C), similarly to that reported during apoptosis in salivary gland acinar cells and in prostate cancer cells $[57,58]$. It is worth mentioning that the cytosol-tomembrane translocations of PKC- $\delta$ and $\mathrm{PKC}-\varepsilon$ due to $\left[\mathrm{Pt}\left(\mathrm{O}, \mathrm{O}^{\prime}\right.\right.$-acac) $(\gamma$-acac)(DMS)] were blocked by inhibiting the $\mathrm{NAD}(\mathrm{P}) \mathrm{H}$ oxidase (Fig. $8 \mathrm{C}$ ). Thus, $\mathrm{NAD}(\mathrm{P}) \mathrm{H}$ oxidase activation leading to MAPKs activation, is a key event in [Pt(O,O'-acac)(Y-acac)(DMS)]-mediating apotosis. Cancer cells often escape apoptotic process by triggering cell survival signallings. A major factor contributing to the survival of central neurons could be the stimulatory effects of the PI3K/Akt pathway. Akt is a critical factor for cell survival by the phosphorylation of a number of pro-survival substrates in response to many different stressors [59-62]. Indeed, we found that the inhibition of PI3K by itself induced apoptosis and potentiated the apoptosis caused by $\left[\mathrm{Pt}\left(\mathrm{O}, \mathrm{O}^{\prime}\right.\right.$-acac $)(\mathrm{Y}$-acac)(DMS)] (Fig. 9A). PI3K inhibition also increased p38MAPK and JNK1/2 phosphorylation induced by $[\mathrm{Pt}(\mathrm{O}, \mathrm{O}$ acac)(y-acac)(DMS)] in the first hour of incubation (Fig. 9D); these data are consistent with other which have been shown Akt to regulate the expression of p38MAPK [63] and JNK1/2 phosphorylation [64]. Thus, Akt has a role in cell survival and is implicated in the development of resistance against paclitaxel, cisplatin, vincristine, and rapamycin in various human solid tumors. Consequently, molecules that block Akt activity may play a significant role in cancer therapy and drug sensitization [65].

In SH-SY5Y cells treated with [Pt(O,O'-acac)(Y-acac)(DMS)], the mitochondrial-derived ROS activated FAK through src-mediated phosphorylation, as shown to occur in other circumstances [25,26]. Besides phosphorylation, FAK function is also controlled by cleavage; indeed $\left[\mathrm{Pt}\left(\mathrm{O}, \mathrm{O}^{\prime}\right.\right.$-acac)( $\mathrm{Y}$-acac)(DMS)] provoked FAK cleavage into an aminoterminal 85 to $100 \mathrm{kDa}$ fragment and a carboxyl-terminal 25 to $35 \mathrm{kDa}$ fragment (Fig. 9B). A similar pattern of FAK cleavage by caspases has been observed in cells undergoing apoptosis [66,67] and in fibroblasts transformed by $v$-src or myc oncogenes [68,69]. Truncated FAK is known to inhibit cell spreading and migration [70]. Furthermore, activated FAK recruits $\mathrm{SH} 2$-containing proteins including $85 \mathrm{kDa}$ subunit of $\mathrm{PI} 3 \mathrm{~K}$, which in turn activates Akt [71]. Consistent with this, inhibition of src strongly reduced Akt phosphorylation in $\left[\mathrm{Pt}\left(\mathrm{O}, \mathrm{O}^{\prime}\right.\right.$-acac)(Y-acac)(DMS)]-treated SH-SY5Y cells (Fig. 9C). 
In summary, $\left[\mathrm{Pt}\left(\mathrm{O}, \mathrm{O}^{\prime}-\mathrm{acac}\right)(\mathrm{\gamma}\right.$-acac $\left.)(\mathrm{DMS})\right]$ is cytotoxic to neuroblastoma cells activating pro-apoptotic signalling and downregulating pro-survival signalling. This occurs through Akt inactivation and intracellular decompartimentalization of Bcl-2-related proteins, such as Bax (Fig. 10). [Pt(O,O'-acac)(y-acac)(DMS)] promotes apoptosis through multiple pathways, all of which clinically relevant to tumorigenesis and progression of neuroblastoma and other cancer types (Muscella et al., 2007, 2008). This broad range of biological activities underscores the in vitro efficacy of $\left[\mathrm{Pt}\left(\mathrm{O}, \mathrm{O}^{\prime}\right.\right.$-acac $)(\mathrm{\gamma}$-acac)(DMS)] in neuroblastoma and warrants further development of this drug as an anticancer agent. 


\section{REFERENCES}

[1] Maris JM, Matthay KK. 1999. Molecular biology of neuroblastoma. J Clin Oncol 17:2264-2279.

[2] Kaneko M, Tsuchida Y, Mugishima H, Ohnuma N, Yamamoto K, Kawa K, Iwafuchi M, Sawada T, Suita S. 2002. Intensified chemotherapy increases the survival rates in patients with stage 4 neuroblastoma with MYCN amplification. J Pediatr Hematol Oncol 24:613621.

[3] Cavaletti G, Tredici G, Marmiroli P, Petruccioli MG, Barajon I, Fabbrica D. 1992. Morphometric study of the sensory neuron and peripheral nerve changes induced by chronic cisplatin (DDP) administration in rats. Acta Neuropathol 84:364-71.

[4] Viktorsson K, Lewensohn R, Zhivotovsky B. 2005. Apoptotic pathways and therapy resistance in human malignancies. Adv Cancer Res 94:143-196.

[5] De Pascali SA, Papadia P, Ciccarese A, Pacifico C, Fanizzi FP. 2005. First examples of $\beta$-diketonate platinum II complexes with sulfoxide ligands. Eur J Inorg Chem 5:788-796.

[6] Muscella A, Calabriso N, De Pascali SA, Urso L, Ciccarese A, Fanizzi FP, Migoni D, Marsigliante S. 2007. New platinum II complexes containing both an $\mathrm{O}, \mathrm{O}^{\prime}$-chelated acetylacetonate ligand and a sulfur ligand in the platinum coordination sphere induce apoptosis in HeLa cervical carcinoma cells. Biochem Pharmacol 74:28-40.

[7] Muscella A, Calabriso N, Fanizzi FP, De Pascali SA, Urso L, Ciccarese A, Migoni D, Marsigliante S. 2008. [Pt(O,O'-acac)(gamma-acac)(DMS)], a new Pt compound exerting fast cytotoxicity in MCF-7 breast cancer cells via the mitochondrial apoptotic pathway. $\mathrm{Br} \mathrm{J}$ Pharmacol 153:34-49.

[8] Muscella A, Urso L, Calabriso N, Vetrugno C, Fanizzi FP, Storelli C, Marsigliante S. 2009. Functions of epidermal growth factor receptor in cisplatin response of thyroid cells. Biochem Pharmacol 77:979-992.

[9] Muscella A, Calabriso N, Vetrugno C, Urso L, Fanizzi FP, De Pascali SA, Marsigliante 
S. 2010. Sublethal concentrations of the platinum(II) complex $\left[\mathrm{Pt}\left(\mathrm{O}, \mathrm{O}^{\prime}\right.\right.$-acac)(gammaacac)(DMS)] alter the motility and induce anoikis in MCF-7 cells. $\mathrm{Br} \mathrm{J}$ Pharmacol 160:1362-1377.

[10] Cerri S, Piccolini VM, Santin G, Bottone MG, De Pascali SA, Migoni D, ladarola P, Fanizzi FP, Bernocchi G. 2010. The developmental neurotoxicity study of platinum compounds. Effects of cisplatin versus a novel $\mathrm{Pt}$ (II) complex on rat cerebellum. Neurotoxicol Teratol. in press. (2010 Sep 29. [Epub ahead of print]) doi:10.1016/j.ntt.2010.09.005

[11] Ross RA, Spengler BA, Biedler JL. 1983. Coordinate morphological and biochimical interconversion of human neuroblastoma cells. J Natl Cancer Inst 71:741-749.

[12] Muscella A, Urso L, Calabriso N, Ciccarese A, Migoni D, Fanizzi FP, Di Jeso B, Storelli C and Marsigliante S. 2005. Differential response of normal, dedifferentiated and transformed thyroid cell lines to cisplatin treatment. Biochem Pharmacol 19: 50-60.

[13] Skehan P, Storeng R, Scudiero D, Monks A, McMahon J, Vistica D, Warren JT, Bokesch H, Kenney S, Boyd MR. 1990. New colorimetric cytotoxicity assay for anticancerdrug screening. J Natl Cancer Inst 82:1107-1112.

[14] Livak KJ, Schmittgen TH. 2001. Analysis of relative gene expression data using realtime quantitative PCR and the 2-DDCT. Methods 25: 402-408.

[15] Muscella A, Calabriso N, Vetrugno C, Fanizzi FP, De Pascali SA, Storelli C, Marsigliante S. 2011. The platinum (II) complex [Pt(O,O'-acac)(gamma-acac)(DMS)] alters the calcium homeostasis in MCF-7 breast cancer cells. Biochem Pharmacol 81:91-103.

[16] Kaufmann SH, Desnoyers S, Ottaviano Y, Davidson NE, Poirier GG. 1993. Specific proteolytic cleavage of poly(ADP-ribose) polymerase: an early marker of chemotherapyinduced apoptosis. Cancer Res 53: 3976-3985.

[17] Boatright KM, Salvensen GS. 2003. Mechanisms of caspase activation. Curr Opin Cell Biol 15:725-731. 
[18] Karin M. 1999. The beginning of the end: I kappa B kinase (IKK) and NF-kappa B activation. J Biol Chem 274: 27339-27342.

[19] Parran DK, Barker A, Ehrich M. 2005. Effects of thimerosal on NGF signal transduction and cell death in neuroblastoma cells. Toxicol Sci 86:132-40.

[20] Hancock JT, Desikan R, Neill SJ. 2001. Does the redox status of cytochrome c act as a fail-safe mechanism in the regulation of programmed cell death? Free Radicals in Biology and Medicine 31:697-703

[21] Shimoke K, Chiba H. 2001. Nerve growth factor prevents 1-methyl-4-phenyl-1,2,3,6tetrahydropyridine-induced cell death via the Akt pathway by suppressing caspase 3 -like activity using PC12 cells relevance to therapeutical application for Parkinson's disease. J Neurosci Res 63:402-409.

[22] Nuutinen U, Postila V, Mättö M, Eeva J, Ropponen A, Eray M, Riikonen P, Pelkonen J. 2006. Inhibition of PI3-kinase-Akt pathway enhances dexamethasone-induced apoptosis in a human follicular lymphoma cell line. Exp Cell Res 312:322-330.

[23] Yu XR, Jia GR, Gao GD, Wang SH, Han Y, Cao W. 2006. Neuroprotection of insulin against oxidative stress-induced apoptosis in cultured retinal neurons involvement of phosphoinositide 3-kinase/Akt signal pathway. Acta Biochim Biophys Sin 38:241-248.

[24] Shi C, Zhao L, Zhu B, Li Q, Yew DT, Yao Z, Xu J. 2009. Protective effects of Ginkgo biloba extract (EGb761) and its constituents quercetin and ginkgolide $B$ against betaamyloid peptide-induced toxicity in SH-SY5Y cells. Chem Biol Interact 181:115-123.

[25] Cheng JJ, Chao YJ, Wang DL. 2002. Cyclic strain activates redox-sensitive prolinerich tyrosine kinase 2 (PYK2) in endothelial cells. J Biol Chem 277: 48152-48157.

[26] Kopetz S, Lesslie DP, Dallas NA, Park SI, Johnson M, Parikh NU, Kim MP, Abbruzzese JL, Ellis LM, Chandra J, Gallick GE. 2009. Synergistic activity of the SRC family kinase inhibitor dasatinib and oxaliplatin in colon carcinoma cells is mediated by oxidative stress. Cancer Res 69:3842-3849. 
[27] Ly JD, Grubb DR, Lawen A. 2003. The mitochondrial membrane potential DYm in apoptosis; an update. Apoptosis 8:115-128.

[28] Reed JC. 2006. Proapoptotic multidomain Bcl-2/Bax-family protein: mechanisms, physiological roles, and therapeutic opportunities. Cell Death Differ 13:1378-1386.

[29] Kroemer G. 1997. The proto-oncogene Bcl-2 and its role in regulating apoptosis. Nat Med 3:614-620.

[30] Allen RT, Cluck MW, Agrawal DK. 1998. Mechanisms controlling cellular suicide: role of Bcl-2 and caspases. Cell Mol Life Sci 54:427-445.

[31] Zhang L, Yu H, Zhao X, Lin X, Tan C, Cao G, Wang Z. 2010. Neuroprotective effects of salidroside against beta-amyloid-induced oxidative stress in SH-SY5Y human neuroblastoma cells. Neurochem Int 57:547-555.

[32] Proskuryakov SY, Konoplyannikov AG, Gabai VL. 2003. Necrosis: a specific form of programmed cell death? Exp Cell Res 283:1-16.

[33] Zhuang S, Demirs JT, Kochevar IE. 2000. p38 mitogen-activated protein kinase mediates Bid cleavage, mitochondrial dysfunction, and caspase-3 activation during apoptosis induced by singlet oxygen, but not by hydrogen peroxide. $J$ Biol Chem 275:25935-25948.

[34] Galan A, GarciaBermejo ML, Troyano A, Vilaboa NE, deBlas E, Kazanietz G, Aller P. 2000. Stimulation of p38 mitogen-activated protein kinase is an early regulatory event for the cadmium-induced apoptosis in human promonocytic cells. J Biol Chem 275:1141811424.

[35] Ko HW, Han KS, Kim EY, Ryu BR, Yoon WJ, Jung YK, Kim SU, Gwag BJ. 2000. Synergetic activation of p38 mitogen-activated protein kinase and caspase-3-like proteases for execution of calyculin A-induced apoptosis but not $\mathrm{N}$-methyl-d-aspartateinduced necrosis in mouse cortical neurons. J Neurochem 74:2455-2461.

[36] Davis RJ. 2000. Signal Transduction by the JNK Group of MAP Kinases II. Cell 
[37] Yamamoto K, Ichijo H, Korsmeyer SJ. 1999. BCL-2 is phosphorylated and inactivated by an ASK1/Jun N-terminal protein kinase pathway normally activated at $\mathrm{G} 2 / \mathrm{M}$. Mol Cell Biol 19:8469-8478.

[38] Yu C, Minemoto Y, Zhang J, Liu J, Tang F, Bui TN, Xiang J, Lin A. 2004. JNK suppresses apoptosis via phosphorylation of the proapoptotic Bcl-2 family protein BAD. Molecular Cell 13:329-340.

[39] Schroeter H, Boyd, CS, Ahmed R, Spencer JP, Duncan RF, Rice-Evans C, Cadenas E. 2003. c-Jun N-terminal kinase JNK-mediated modulation of brain mitochondria function: new target proteins for JNK signalling in mitochondrion-dependent apoptosis. Biochem $\mathrm{J}$ 372:359-369.

[40] Lee SJ, Kim MS, Park JY, Woo JS, Kim YK. 2008. 15-Deoxy-delta12,14-prostaglandin J2 induces apoptosis via JNK-mediated mitochondrial pathway in osteoblastic cells. Toxicology 248:121-129.

[41] Kim BJ, Ryu SW, Song BJ. 2006. JNK and p38 kinase-mediated phosphorylation of Bax leads to its activation and mitochondrial translocation and to apoptosis of human hepatoma HepG2 cells. J Biol Chem 28:21256-21265.

[42] Breitschopf K, Haendeler J, Malchow P, Zeiher AM, Dimmeler S. 2000. Posttranslational modification of $\mathrm{Bcl}-2$ facilitates its proteasome-dependent degradation: molecular characterization of the involved signaling pathway. Mol Cell Biol 20:1886-1896.

[43] Lee $\mathrm{Jl}$ and Burckart GL.1998. Nuclear factor kB: important transcription factor and therapeutic target. J Clin Pharmacol 38:981-993.

[44] Uberti D, Carsana T, Francisconi S, Ferrari Toninelli G, Canonico PL, Memo M. 2004. A novel mechanism for pergolide-induced neuroprotection: inhibition of NF-kappaB nuclear translocation. Biochem Pharmacol 67:1743-1750.

[45] Wu J, Harris NL, Inge TH. 2004. Nuclear factor-kappa B and apoptosis inducing factor 
activation by doxorubicin analog WP744 in SH-SY5Y neuroblastoma cells. J Surg Res 122:231-239.

[46] Song YS, Park HJ, Kim SY, Lee SH, Yoo HS, Lee HS, Lee MK, Oh KW, Kang SK, Lee SE, Hong JT. 2004. Protective role of Bcl-2 on beta-amyloid-induced cell death of differentiated PC12 cells: Reduction of NF-kappaB and p38MAPkinase activation. Neurosci Res 49:69-80.

[47] Kundu K, Shin YK, Surh YJ. 2006. Resveratrol modulates phorbol ester-induced proinflammatory signal transduction pathways in mouse skin in vivo: NF-KB and AP-1 as prime targets. Biochem Pharmacol 72:1506-1515.

[48] Xu C, Shen G, Yuan X, Kim JH, Gopalkrishnan A, Keum YS, Nair S, Kong AN. 2006. ERK and JNK signaling pathways are involved in the regulation of activator protein 1 and cell death elicited by three isothiocyanates in human prostate cancer PC-3 cells. Carcinogenesis 27:437-445.

[49] Kelicen P, Cantuti-Castelvetri I, Pekiner C, Paulson KE. 2002. The spin trapping agent PBN stimulates $\mathrm{H} 2 \mathrm{O} 2$-induced ERK and src kinase activity in human neuroblastoma cells.Neuroreport 13:1057-1061.

[50] Brand A, Gil S, Seger R, Yavin E. 2001. Lipid constituents in oligodendroglial cells alter susceptibility to $\mathrm{H} 2 \mathrm{O} 2$-induced apoptotic cell death via ERK activation. J Neurochem 76:910-918.

[51] Stanciu M, Wang Y, Kentor R, Burke N, Watkins S, Kress G, Reynolds I, Klann E, Angiolieri MR, Johnson JW, DeFranco DB. 2000. Persistent activation of ERK contributes to glutamate-induced oxidative toxicity in a neuronal cell line and primary cortical neuron cultures. J Biol Chem 275:12200-12206.

[52] Kakkar P and Singh BK. 2007. Mitochondria: a hub of redox activities and cellular distress control. Mol Cell Biochem 305:235-253.

[53] Xuan YT, Guo Y, Zhu Y, Wang OL, Rokosh G, Messing RO, Bolli R. 2005. Role of the protein kinase C- $\varepsilon$-Raf-1-MEK-1/2-p44/42 MAPK signaling cascade in the activation of 
signal transducers and activators of transcription 1 and 3 and induction of cyclooxygenase2 after ischemic preconditioning Circulation 112:1971-1978.

[54] Besson A, Davey A, Robbins SM, Yong VW. 2001. Differential activation of ERKs to focal adhesions by PKCE is required for PMA-induced adhesion and migration of human glioma cells. Oncogene 20:7398-7407.

[55] Basu A and Tu H. 2005. Activation of ERK during DNA damage-induced apoptosis involves protein kinase $\mathrm{C}$ delta. Biochem Biophys Res Commun 334:1068-1073.

[56] Knauf JA, Elisei R, Mochly-Rosen D, Liron T, Chen XN, Gonsky R Korenberg JR, Fagin JA. 1999. Involvement of protein kinase C-epsilon PKCepsilon in thyroid cell death A truncated chimeric PKCepsilon cloned from a thyroid cancer cell line protects thyroid cells from apoptosis. J Biol Chem 274:23414-23425.

[57] Reyland ME, Barzen KA, Anderson SM, Quissell DO, Matassa AA. 2000. Activation of $P K C$ is sufficient to induce an apoptotic program in salivary gland acinar cells.Cell Death Differ 7:1200-1209.

[58] Tanaka Y, Gavrielides MV, Mitsuuchi Y, Fujii T, Kazanietz MG. 2003. Protein kinase C promotes apoptosis in LNCaP prostate cancer cells through activation of p38 MAPK and inhibition of the Akt survival pathway. J Biol Chem 278:33753-33762.

[59] Salinas M, Martin D, Alvarez A, Cuadrado A. 2001. Akt1/PKBalpha protects PC12 cells against the parkinsonism-inducing neurotoxin 1-methyl-4-phenylpyridinium and reduces the levels of oxygen-free radicals. Mol Cell Neurosci 17:67-77.

[60] Yamaguchi A, Tamatani M, Matsuzaki H, Namikawa K, Kiyama H, Vitek MP, Mitsuda N, Tohyama M. 2001. Akt activation protects hippocampal neurons from apoptosis by inhibiting transcriptional activity of p53. J Biol Chem 276: 5256-5264.

[61] Nicholson KM and Anderson NG. 2002. The protein kinase B/Akt signalling pathway in human malignancy. Cell Signal 14:381-395.

[62] Chen HK, Fernandez-Funez P, Acevedo SF, Lam YC, Kaytor MD, Fernandez MH, 
Aitken A, Skoulakis EM, Orr HT, Botas J, Zoghbi HY. 2003. Interaction of Aktphosphorylated ataxin-1 with 14-3-3mediates neurodegeneration in spinocerebellar ataxia type 1. Cell 113:457-468.

[63] Liao $Y$ and Hung MC. 2003. Regulation of the activity of p38 mitogen-activated protein kinase by Akt in cancer and adenoviral protein E1A-mediated sensitization to apoptosis. Mol Cell Biol 23:6836-6848.

[64] Tsuruta F, Sunayama J, Mori Y Hattori S, Shimizu S, Tsujimoto Y, Yoshioka K,. Masuyama N, Gotoh Y. 2004. JNK promotes Bax translocation to mitochondria through phosphorylation of 14-3-3 proteins. Embo J 23:1889-1899.

[65] Kim D, Cheng GZ, Lindsley CW, Yang H, Cheng JQ. 2005. Targeting the phosphatidylinositol-3 kinase/Akt pathway for the treatment of cancer. Curr Opin Invest Drugs 6:1250-1258.

[66] Wen LP, Fahrni JA, Troie S, Guan JL, Orth K, Rosen GD. 1997. Cleavage of focal adhesion kinase by caspases during apoptosis. J Biol Chem 272:26056-26061.

[67] Gervais FG, Thornberry NA, Ruffolo SC, Nicholson DW, Roy S. 1998. Caspases cleave focal adhesion kinase during apoptosis to generate a FRNK-like polypeptide. J Biol Chem 273:17102-17108.

[68] Fincham VJ, Wyke JA, Frame MC. 1995. v-Src-induced degradation of focal adhesion kinase during morphological transformation of chicken embryo fibroblasts. Oncogene 10:2247-2252.

[69] Crouch DH, Fincham VJ, Frame MC. 1996. Targeted proteolysis of the focal adhesion kinase pp125 FAK during C-MYC-induced apoptosis is suppressed by integrin signalling. Oncogene 12:2689-2696.

[70] Shofuda K, Moriyama K, Nishihashi A, Higashi S, Mizushima H, Yasumitsu H, Miki K, Sato H, Seiki M, Miyazaki K. 1998. Role of tissue inhibitor of metalloproteinases-2 (TIMP2) in regulation of pro-gelatinase $A$ activation catalyzed by membrane-type matrix metalloproteinase-1 (MT1-MMP) in human cancer cells. J Biochem 124:462-470. 
[71] Mookherjee P, Quintanilla R, Roh MS, Zmijewska AA, Jope RS, Johnson GV. 2007. Mitochondrial-targeted active Akt protects SH-SY5Y neuroblastoma cells from staurosporine-induced apoptotic cell death. J Cell Biochem 102:196-210. 


\section{LEGENDS TO FIGURES}

Figure 1. The sensitivity of SH-SY5Y cells to $\left[\mathrm{Pt}\left(O, O^{\prime}\right.\right.$-acac $)(\mathrm{Y}$-acac)(DMS $\left.)\right]$ and cisplatin. Cells were treated with and without increasing concentrations of cisplatin and $\left[\mathrm{Pt}\left(\mathrm{O}, \mathrm{O}^{\prime}\right.\right.$-acac $)(\mathrm{Y}$-acac)(DMS)]. Viable cell number was determined $12(\mathrm{~A}), 24(\mathrm{~B}), 48(\mathrm{C})$ and $72 \mathrm{~h}$ (D) later by MTT assay. The data are means \pm S.D. of four different experiments, with eight replicates in each, and are presented as $\%$ of control. Values with shared letters are not significantly different according to Bonferroni/Dunn post hoc tests.

Figure 2. Different dynamics of $\left[\mathrm{Pt}\left(O, O^{\prime}\right.\right.$-acac)( $\gamma$-acac)(DMS)] and cisplatin effects on SH-SY5Y cells.

A) Cells were continuously exposed to $100 \mu \mathrm{M}$ cisplatin or $10 \mu \mathrm{M} \quad\left[\mathrm{Pt}\left(O, O^{\prime}\right.\right.$-acac $)(\mathrm{Y}$ acac)(DMS)], and cell viability was monitored by MTT assay over a period of $24 \mathrm{~h}$. The data are means \pm s.d. of four different experiments each with eight replicates and are presented as $\%$ of control.

B) The $\mathrm{IC}_{50}$ values after $12,24,48$ and $72 \mathrm{~h}$ exposure to cisplatin and $\left[\mathrm{Pt}\left(O, O^{\prime}\right.\right.$-acac $)\left(\gamma^{-}\right.$ acac)(DMS)]

C) Quantification of the percentage of apoptotic nuclei obtained from cells stained with DAPI (means \pm s.d.; $n=4)$, after treatment for different times with $10 \mu \mathrm{M}\left[\mathrm{Pt}\left(O, O^{\prime}\right.\right.$-acac $)\left(\mathrm{Y}^{-}\right.$ acac)(DMS)] or $100 \mu \mathrm{M}$ cisplatin.

D) Clonogenic survival assay in $\mathrm{SH}-\mathrm{SY} 5 \mathrm{Y}$ cells treated with $\left[\mathrm{Pt}\left(O, O^{\prime}\right.\right.$-acac $)(\mathrm{Y}$-acac)(DMS)] or cisplatin. Cells were exposed to the indicated amounts of cisplatin or $\left[\mathrm{Pt}\left(O, O^{\prime}\right.\right.$-acac $)\left(\gamma^{-}\right.$ acac)(DMS)] for $2 \mathrm{~h}$ and, after 15 days of growth, colonies consisting of more than 50 cells were scored. The percentage survival shown represents the mean \pm s.d. of four independent experiments each performed in duplicate. Values with shared letters are not significantly different according to Bonferroni/Dunn post hoc tests.

Figure 3. Effect of cisplatin and $\left[\mathrm{Pt}\left(O, O^{\prime}\right.\right.$-acac $)(\mathrm{Y}$-acac)(DMS $\left.)\right]$ on the activation of caspase-7 -9 and -3 , the cleavage of PARP and on anti- and proapoptotic proteins. Cytosolic and nuclear proteins were obtained from SH-SY5Y cells, treated or not with 10 $\mu \mathrm{M}\left[\mathrm{Pt}\left(O, O^{\prime}\right.\right.$-acac)(Y-acac)(DMS)] (right) or $100 \mu \mathrm{M}$ cisplatin (left). Samples were dissolved in SDS sample buffer and separated on SDS gel. Immunoblotting was performed using monoclonal antibodies anti-caspases-7, -9 , and -3, anti-PARP, anti-Bax and anti-Bcl2 proteins. Sequential incubation with anti-actin confirmed equal protein loading. These 
results are representative of four independent experiments.

Figure 4. Effect of $\left[\mathrm{Pt}\left(O, O^{\prime}\right.\right.$-acac)(Y-acac)(DMS)] on $\Delta \psi \mathrm{m}$, apoptotic and signal transduction proteins in SH-SY5Y cells.

A) Fluorescent spectra of JC-1 in SH-SY5Y cells treated or not with $10 \mu \mathrm{M}\left[\mathrm{Pt}\left(\mathrm{O}, \mathrm{O}^{\prime}-\right.\right.$ acac)( $\gamma$-acac)(DMS)] for the indicated time. The data are means \pm s.d. of three different experiments and are presented as red J-aggregates/green monomer JC-1 fluorescence ratio. Asterisks indicate values that are significantly different $(P<0.05)$ from control at the same concentration and time point.

B) Mitochondrial fractions were prepared at the indicated times of $\left[\mathrm{Pt}\left(O, O^{\prime}\right.\right.$-acac $)\left(\mathrm{Y}^{-}\right.$ acac)(DMS)] treatment, and the kinetics of Bax and Bcl-2 cytosol-to-mitochondria translocations and the release of cytochrome $c$ were examined. Porin served as a mitochondrial indicator.

C) Cells were treated or not with $10 \mu \mathrm{M}\left[\mathrm{Pt}\left(\mathrm{O}, \mathrm{O}^{\prime}\right.\right.$-acac)(y-acac)(DMS)] for indicated time. Cell lysates were analysed by Western blotting with anti- unphosphorylated and phosphorylated p38MAPK, ERK1/2, JNK1/2, and Akt antibodies.

IP: the immunoprecipitated sample obtained by a specific anti total JNK3 monoclonal antibody was analysed by Western blotting using an anti- unphosphorylated (JNK3) and phosphorylated (pJNK3) antibodies.

The same blots were stripped and reprobed with an anti- $\beta$-actin monoclonal antibody. Representative immunoblots of three experiments are depicted.

\section{Figure 5. Role of p38MAPK and JNK1/2 on $\mathrm{Pt}\left(0, \mathrm{O}^{\prime}\right.$-acac)(Y-acac)(DMS)]-induced} apoptosis. Cells were pretreated with SB203580 (1-10 $\mathrm{MM})(\mathbf{A})$ or with SP600125 (1-10 $\mu \mathrm{M})(\mathbf{B})$ and then incubated or not with $10 \mu \mathrm{M}\left[\mathrm{Pt}\left(O, O^{\prime}\right.\right.$-acac) $(\mathrm{\gamma}$-acac)(DMS)]. Upper panel - Cell viability was monitored by MTT assay after $24 \mathrm{~h}$. The percentage of survival shown represents the mean \pm s.d. of four independent experiments each performed in duplicate. Values with shared letters are not significantly different according to Bonferroni/Dunn post hoc tests.

Bottom panel - Cytosolic and mitochondrial fractions were analysed by Western blotting with antibodies against cytochrome c (Cyt.c), activated caspases (t-casp-9 and t-casp-7) , Bax and Bcl-2. Porin served as an indicator for mitochondrial contamination of cytosolic extracts whilst $\beta$-actin was used as a control for protein loading. Representative immunoblots of three experiments are depicted. 


\section{Figure 6. Pt(O,O'-acac)(y-acac)(DMS)] induces NF-KB activation.}

A) Cells were treated or not with $10 \mu \mathrm{M}\left[\mathrm{Pt}\left(\mathrm{O}, \mathrm{O}^{\prime}\right.\right.$-acac $)(\mathrm{\gamma}$-acac)(DMS)] for different times and then RNA was extracted. Upper panel: RNA was reverse-transcribed and amplified with specific primers for $\mathrm{BAX}$ and $\mathrm{Bcl}-2$ and for the housekeeping gene $\beta$-actin to normalised the amount of DNA template used in each PCR reaction. The figures are representative of three independent experiments. Bottom panel: samples were analysed by real-time PCR. mRNA levels were normalised to $\beta$-actin and calculated as fold change values relative to control. Data were expressed as the the mean \pm s.d. of three different experiments.

B) Cells were treated or not with $10 \mu \mathrm{M}\left[\mathrm{Pt}\left(\mathrm{O}, \mathrm{O}^{\prime}\right.\right.$-acac $)(\mathrm{Y}$-acac)(DMS)] for different time periods and then cytosol (cyt) and nuclear (nuc) fractions were analyzed by Western blotting with specific anti-lkB- $\alpha$ or anti-p65 NF-Kb antibodies. The purity of fractions was tested by immunoblotting with anti-histone-3/4 (H3/4) polyclonal and anti $\beta$-actin monoclonal antibodies. Representative immunoblots of three experiments are depicted.

(C) Cells, pretreated with PD98059 (10-30 $\mu \mathrm{M})$, were incubated or not with $10 \mu \mathrm{M}$ $\left[\mathrm{Pt}\left(O, O^{\prime}\right.\right.$-acac) $(\mathrm{Y}$-acac)(DMS)] for $24 \mathrm{~h}$. Then, (upper panel) Western blotting performed using an anti- unphosphorylated and phosphorylated ERK1/2 and anti-caspase-9 antibodies and (bottom panel) cell viability was monitored by MTT assay.

Actin was used as a control for protein loading. Representative immunoblots of three experiments are depicted.

The percentage of cell survival shown represents the meants.d. of four independent experiments each performed in duplicate. Values with shared letters are not significantly different according to Bonferroni/Dunn post hoc tests.

D) Cells pretreated with $10 \mu \mathrm{M}$ quinazoline (QNZ) or with $30 \mu \mathrm{M}$ PD98059 or transfected with siRNA-p65 (or with control siRNA (NS)) were incubated or not with $10 \mu \mathrm{M}\left[\mathrm{Pt}\left(O, O^{\prime}\right.\right.$ acac)( $\gamma$-acac)(DMS)]. Cytosol (cyt) and nuclear (nuc) fractions were analyzed by Western blotting with anti-BAX, -Bcl-2 or -p65 antibodies. The purity of fractions was tested by immunoblotting with anti-histone-3/4 (H3/4) polyclonal and anti $\beta$-actin monoclonal antibodies. Representative immunoblots of three experiments are depicted.

Figure 7. PKCs activation and their transductional roles in $\mathrm{Pt}\left(0, \mathrm{O}^{\prime}\right.$-acac)( $\mathrm{Y}$ acac)(DMS)]-treated cells.

(A) SH-SY5Y cells were treated without or with $10 \mu \mathrm{M}\left[\mathrm{Pt}\left(O, \mathrm{O}^{\prime}\right.\right.$-acac $)(\mathrm{Y}$-acac)(DMS)] for the indicated times. For PKCs translocation studies, cytosol (cyt) and membrane (mem) fractions were analyzed by Western blotting with specific antibodies. The purity of fractions 
was tested with anti $\beta$-actin and anti- $\alpha$ subunit of $\mathrm{Na}^{+} / \mathrm{K}^{+}$ATPase monoclonal antibodies. The figures are representative of four independent experiments. (B,C and D) Cells were transfected with siRNA-PKC- $\varepsilon,-P K C-\delta$ and $-P K C-\alpha$ or with control siRNA (NS) and then were incubated with $10 \mu \mathrm{M}\left[\mathrm{Pt}\left(O, O^{\prime}\right.\right.$-acac $)(\mathrm{Y}$-acac $\left.)(\mathrm{DMS})\right]$. Western blotting of total lysates was performed with specific anti-PKCs (B), or with anti- unphosphorylated and phosphorylated p38MAPK, and JNK1/2 antibodies (C) or with anti- unphosphorylated and phosphorylated ERK1/2, anti-IkBa, anti-Bcl-2 and anti-BAX antibodies (D). Western blotting of nuclear extracts was performed with specific anti-p65 antibody (D). The purity of fractions was tested with anti-histone-3/4 (H3/4) polyclonal and anti $\beta$-actin monoclonal antibodies. Representative immunoblots of three experiments are depicted.

\section{Figure 8. $\left[\mathrm{Pt}\left(O, O^{\prime}\right.\right.$-acac $)(\mathrm{Y}$-acac)(DMS)] induces MAPKs activation through ROS} generation. A) SH-SY5Y cells were pre-incubated or not with DPI for $30 \mathrm{~min}$ and then exposed to $10 \mu \mathrm{M}\left[\mathrm{Pt}\left(O, O^{\prime}\right.\right.$-acac $)(\mathrm{Y}$-acac)(DMS)] for the indicated times. ROS production was measured by NBT reduction. Values with shared letters are not significantly different according to Bonferroni/Dunn post hoc tests. (B) Cells pre-incubated with apocynin for 30 min were exposed to $\left[\mathrm{Pt}\left(O, O^{\prime}\right.\right.$-acac $)(\gamma$-acac $\left.)(D M S)\right]$ and specific production of mitochondrial $\mathrm{O}^{-}$was measured using the cell-permeable probe MitoSOX Red. The emitted red fluorescence after $488 \mathrm{~nm}$ excitation, was measured with a chopper interval of $0.5 \mathrm{~s}$ and the emission monochromator was set at $580 \mathrm{~nm}$. (C and D) Cells pre-incubated with apocynin or DPI for 30 min were exposed to $\left[\mathrm{Pt}\left(O, O^{\prime}\right.\right.$-acac $)(\gamma$-acac $\left.)(D M S)\right]$ for further 30 min. (C) Membrane fractions (mem) were analysed by Western blotting with specific anti- PKC- $\varepsilon$ and PKC- $\delta$ antibodies. The purity of fractions was tested with anti- $\alpha$ subunit of $\mathrm{Na}^{+} / \mathrm{K}^{+}$ATPase monoclonal antibody. (D) Cell lysates were analysed by Western blotting with anti-phosphorylated or anti-total (unphosphorylated and phosphorylated) p38MAPK, ERK1/2 and JNK1/2 antibodies. Control loadings are shown by $\beta$-actin. The figures are representative of four independent experiments.

\section{Figure 9. [Pt(O,O'-acac)(Y-acac)(DMS)] activates c-src and Fak}

(A) SH-SY5Y cells were pre-incubated or not with LY 294002 for 30 min and then exposed to $10 \mu \mathrm{M}\left[\mathrm{Pt}\left(O, O^{\prime}\right.\right.$-acac $)(\mathrm{Y}$-acac)(DMS)] for the indicated times; viable cell number was determined by MTT assay. The data are means \pm S.D. of four different experiments, with eight replicates in each, and are presented as \% of control. Values with shared letters are not significantly different according to Bonferroni/Dunn post hoc tests. (B) Cell lysates were analysed by Western blotting with anti- phosphorylated src (p-src) and 
phosphorylated FAK (p-FAK) antibodies. The same blots were stripped and reprobed with an anti- $\beta$-actin monoclonal antibody. Representative immunoblots of three experiments are depicted. (C and D) SH-SY5Y cells pre-incubated or not with the src inhibitor PP1 or apocynin (C) or with LY 294002 or SB203580 (D) for 30 min were then exposed to $10 \mu \mathrm{M}$ $\left[\mathrm{Pt}\left(O, O^{\prime}\right.\right.$-acac) $(\mathrm{Y}$-acac)(DMS)] and cell lysates were analysed by Western blotting with antiphosphorylated src (p-src), phosphorylated p38MAPK (p-p38MAPK), phosphorylated Akt (p-Akt), phosphorylated JNK1/2 (p-JNK1/2) and with truncated caspase-7 (t-casp-7) antibodies. Control loadings are shown by $\beta$-actin. The figures are representative of four independent experiments.

Fig. 10. [Pt( $O, O^{\prime}$-acac)(Y-acac)(DMS)] have a dual effect on human neuroblastoma cell line. $\left[\mathrm{Pt}\left(O, O^{\prime}\right.\right.$-acac $)(\gamma$-acac $\left.)(D M S)\right]$ activates apoptotic mechanisms $(A)$ and downregulates pro-survival pathways (B) starting from mitochondrial ROS generation. 

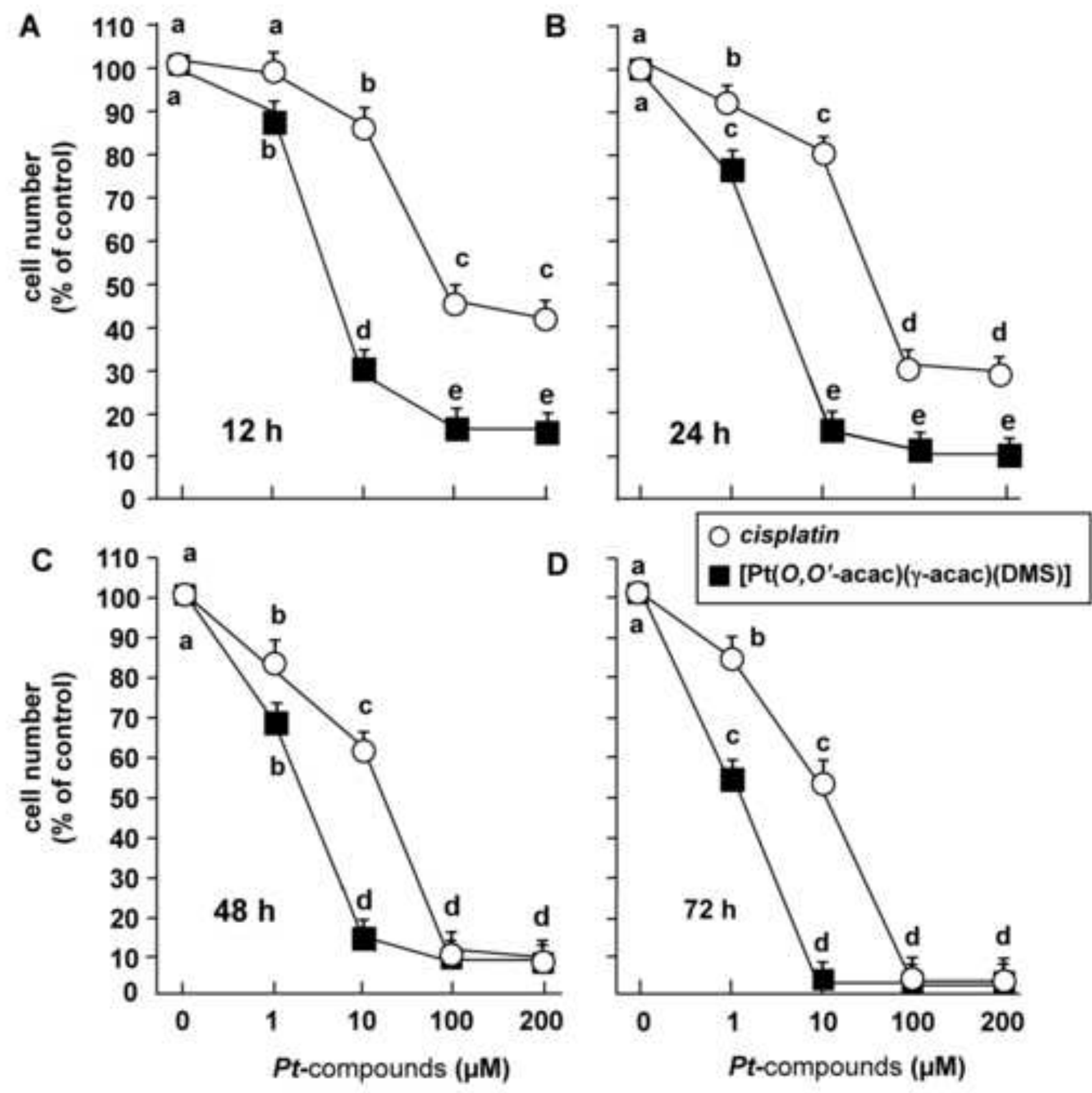

Fig 1 


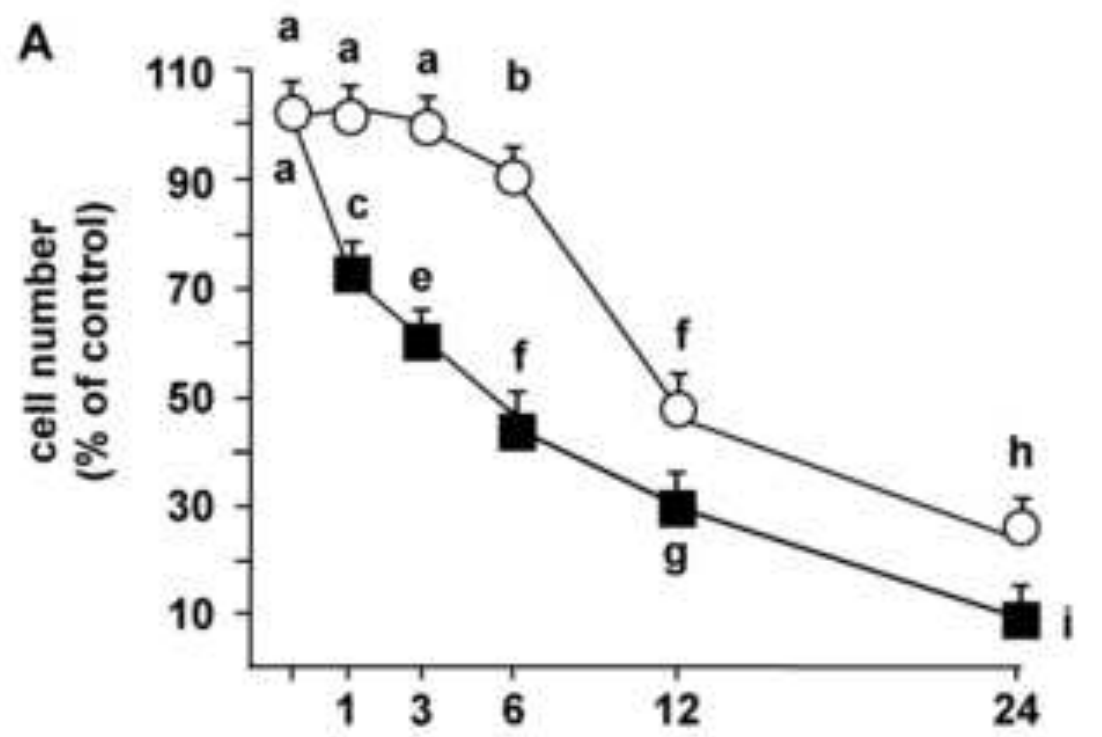

B

$$
I C_{50}(\mu M)
$$

Time (h) cisplatin Pt(acac) ${ }_{2}$ DMS significantly

$12 \quad 99.4 \pm 13.2 \quad 6.5 \pm 0.7 \quad$ p $<0,001$

$24 \quad 50.8 \pm 1.2 \quad 4.2 \pm 0.2 \quad$ p $<0,0001$

$48 \quad 26.5 \pm 2 \quad 3.3 \pm 0.2 \quad p<0,001$

$\begin{array}{llll}72 & 9.8 \pm 1.2 & 1.5 \pm 0.3 & p<0,01\end{array}$
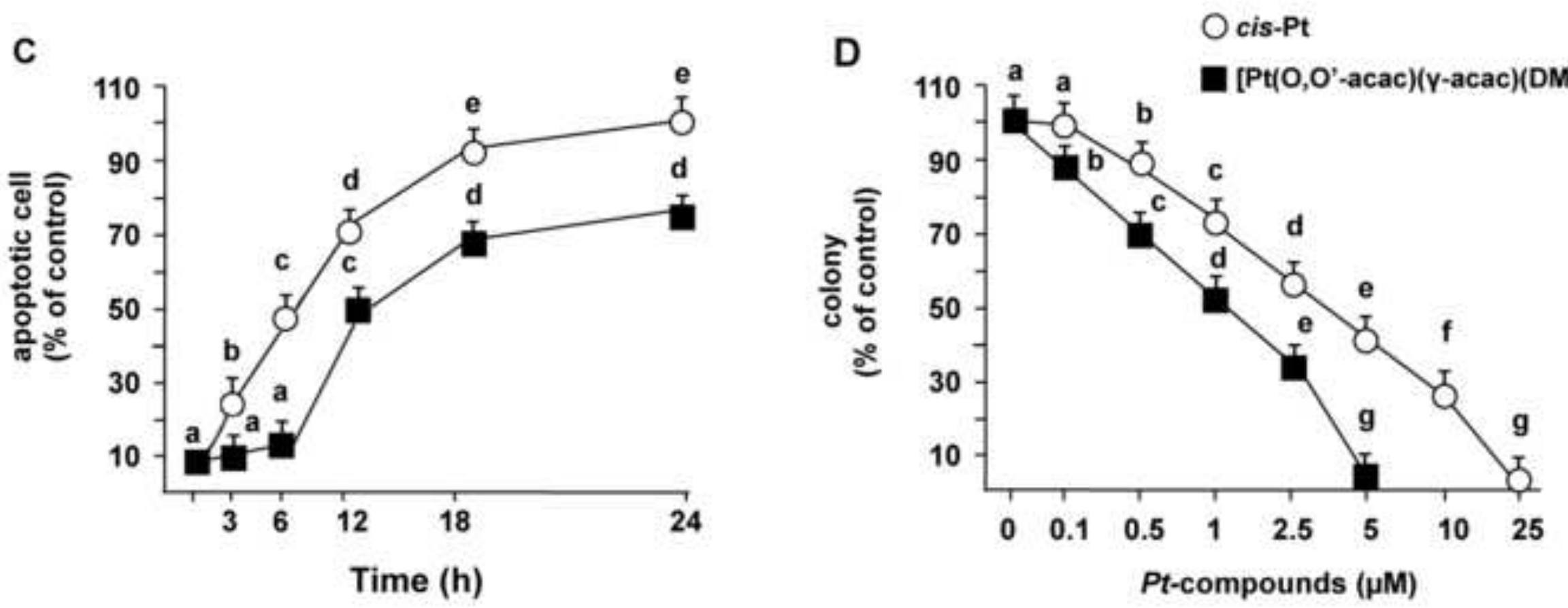

Fig 2 

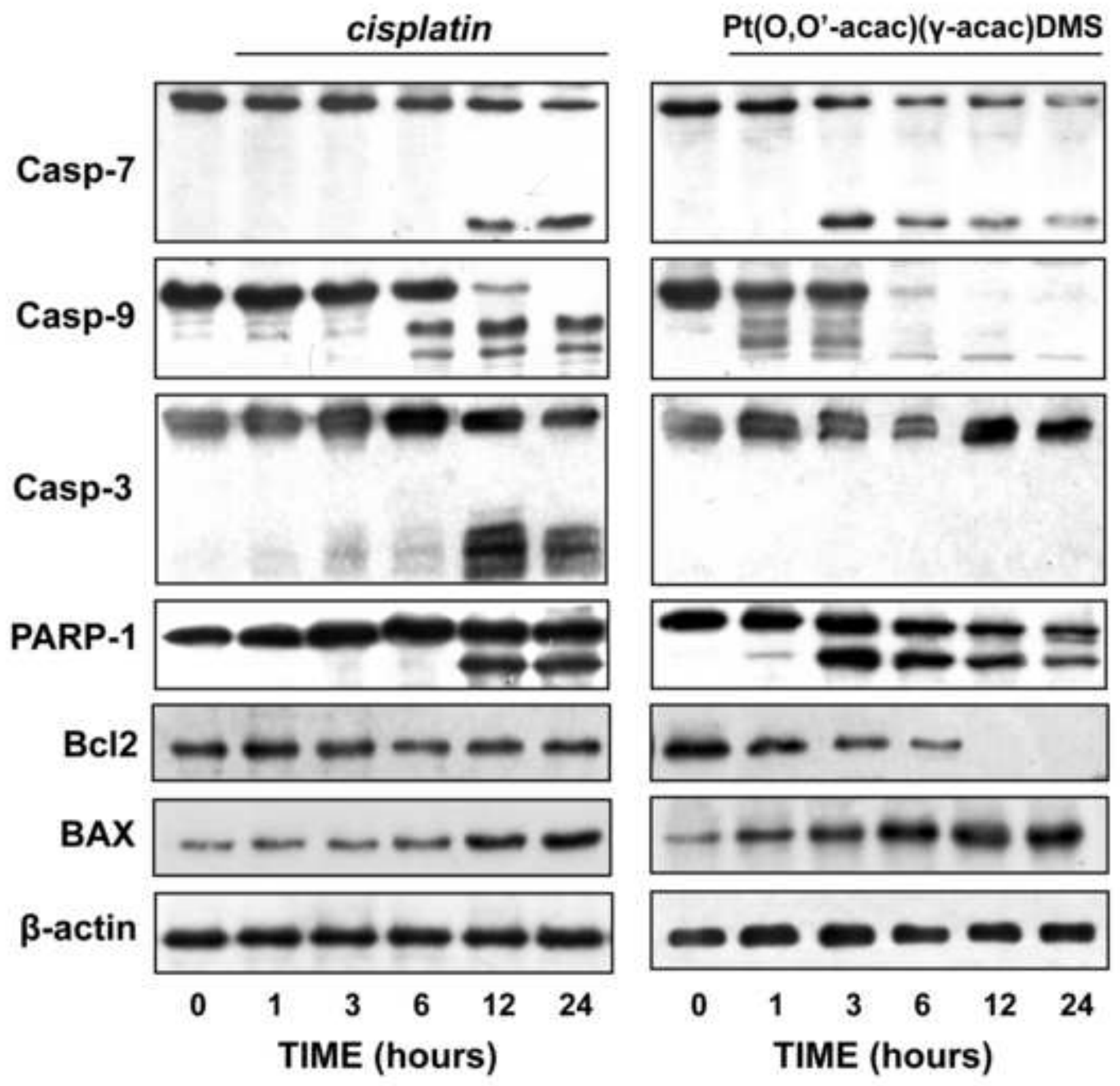

Fig 3 
A

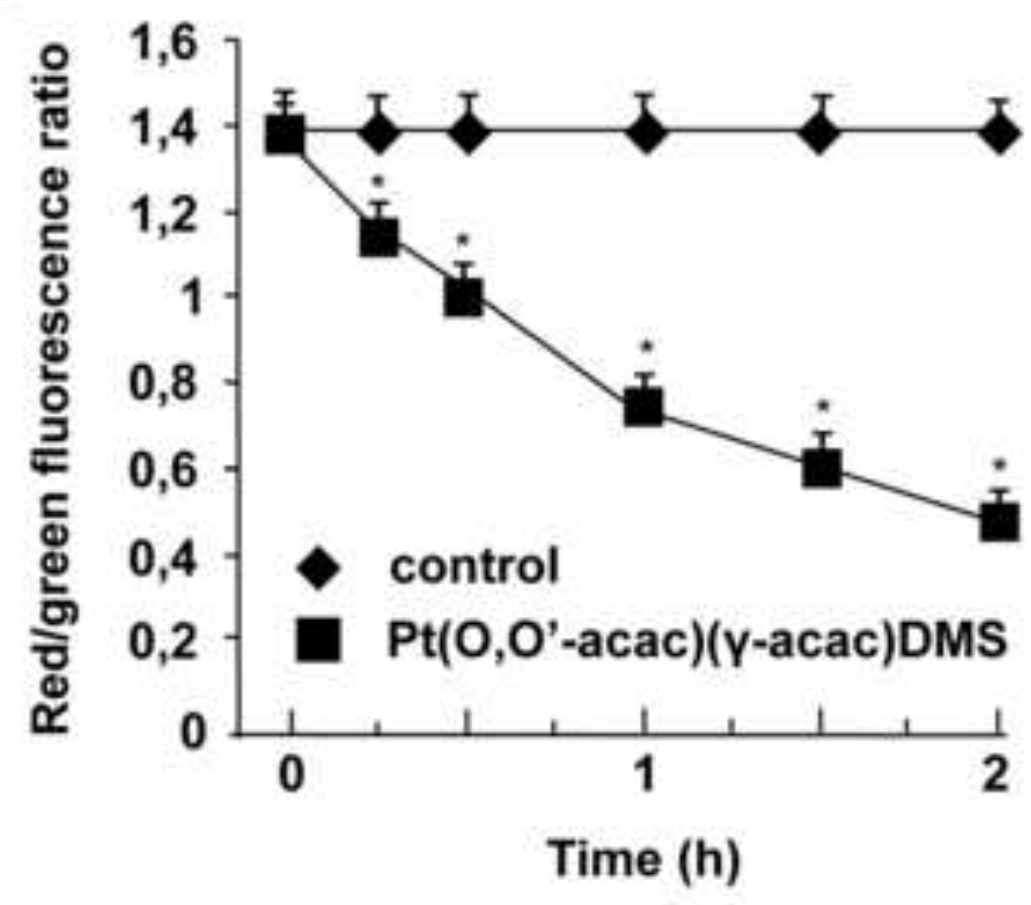

B

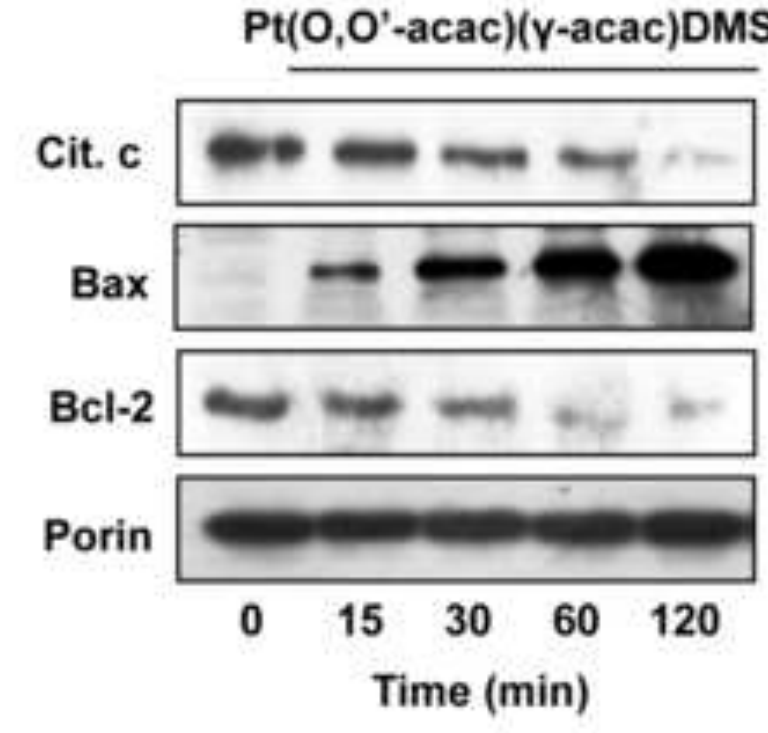

C

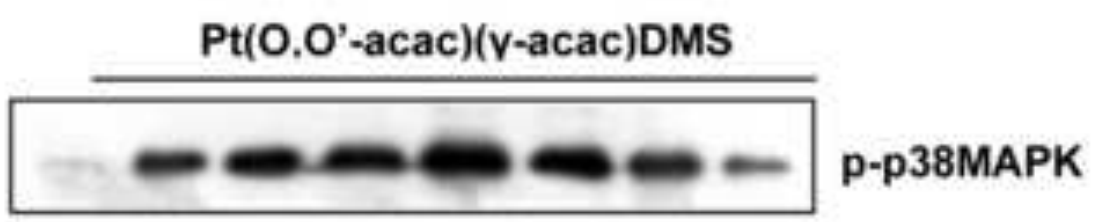
$-\infty \omega \infty \omega \infty$ p38MAPK

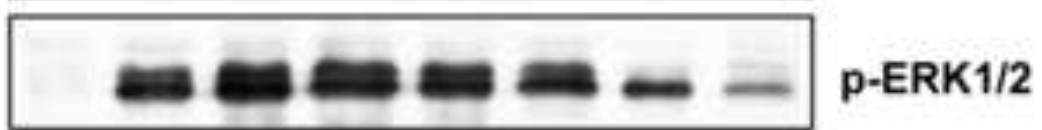
as a

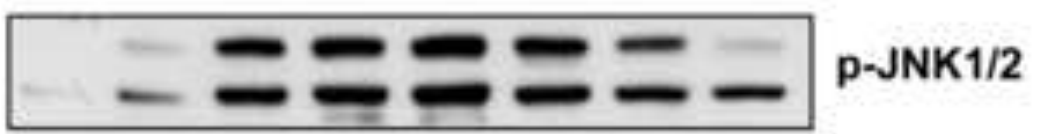

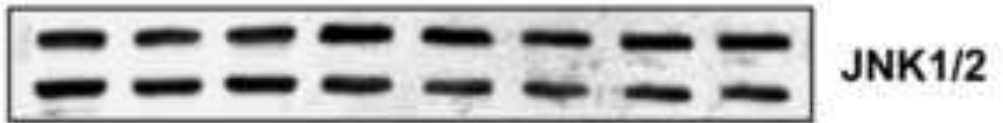

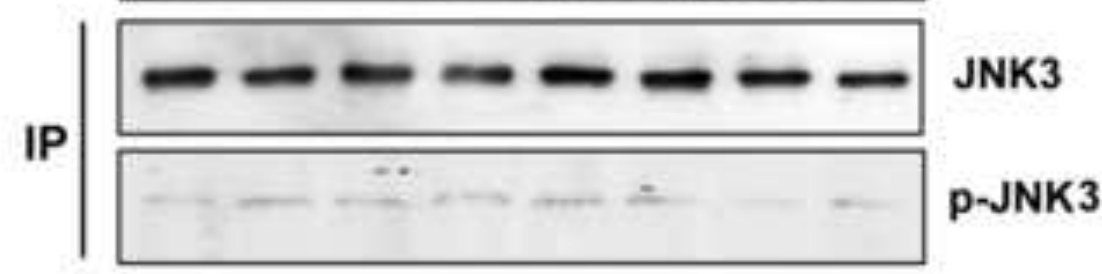
$-\infty-\infty-\infty$ p-Akt

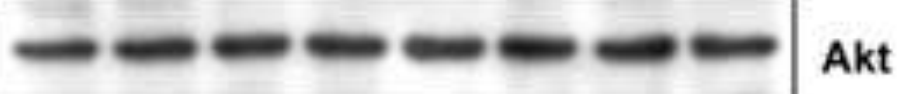

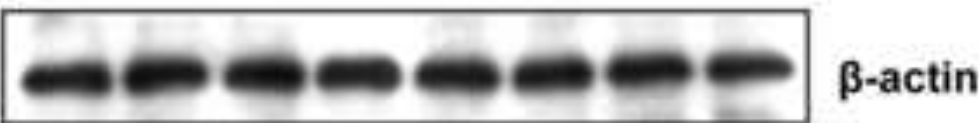

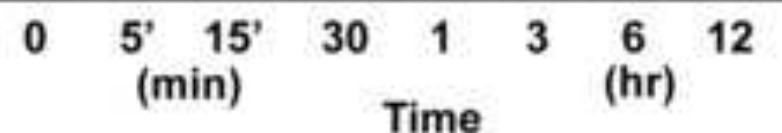

Fig 4 


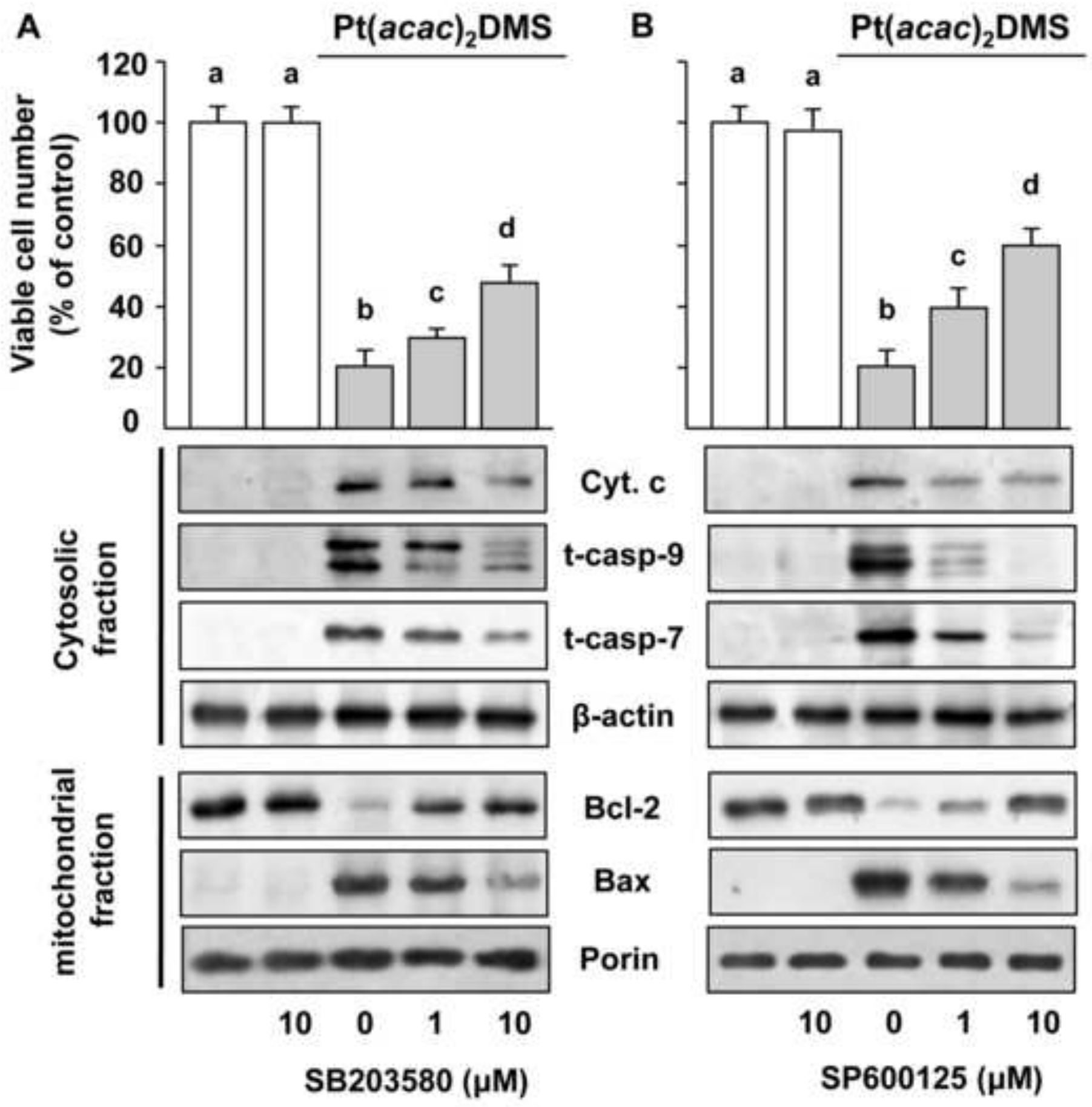

Fig 5 
A
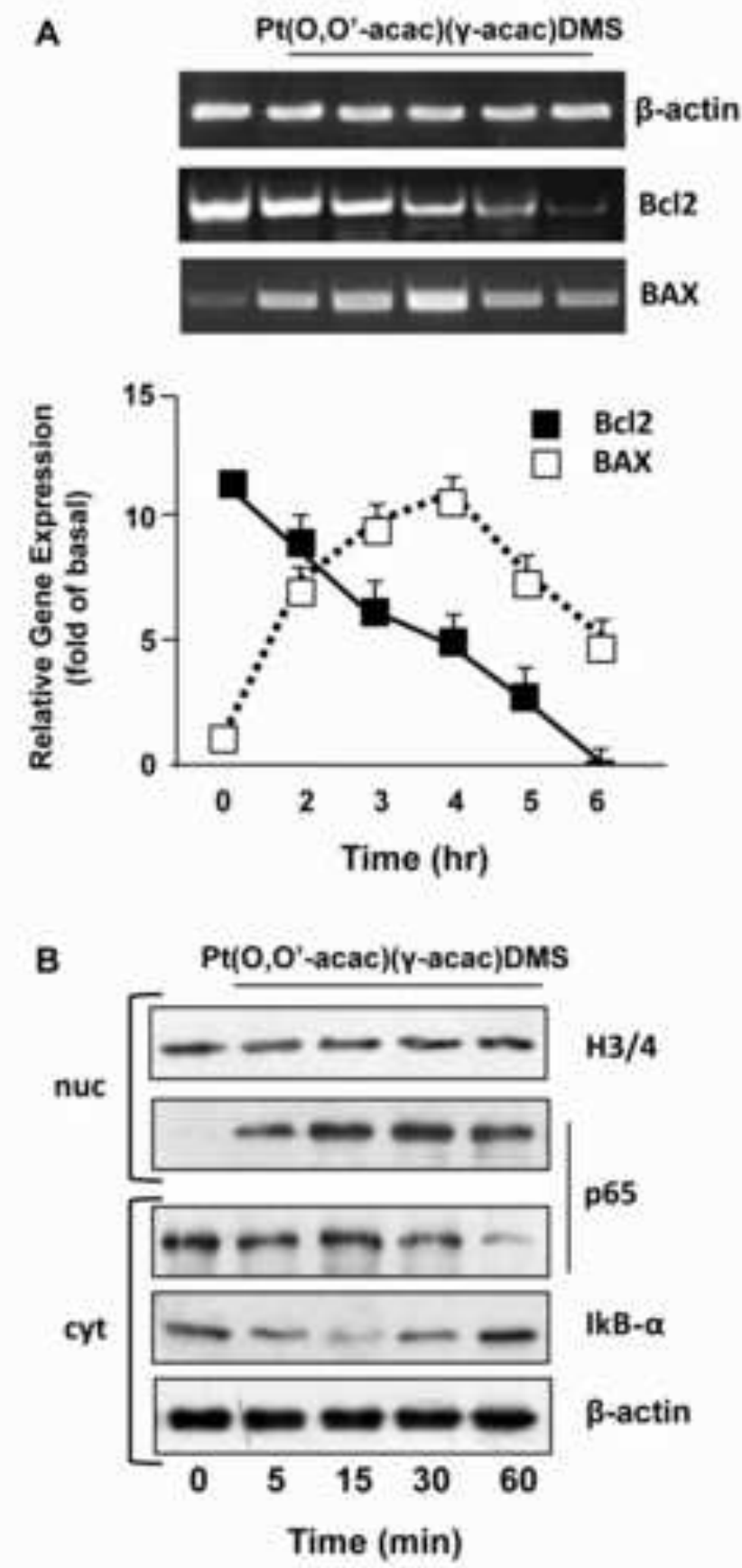

C

\section{Pt(O,O'-acac) $(Y$-acac $)$ DMS}
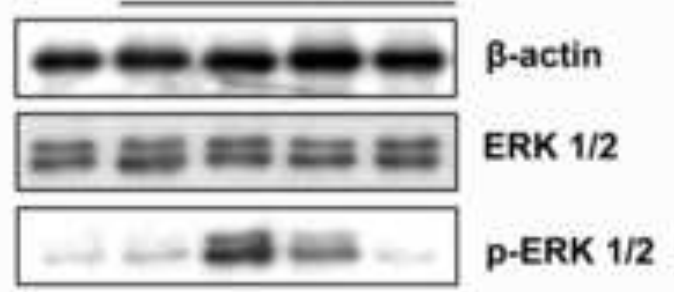

$= \pm$ t-casp-9

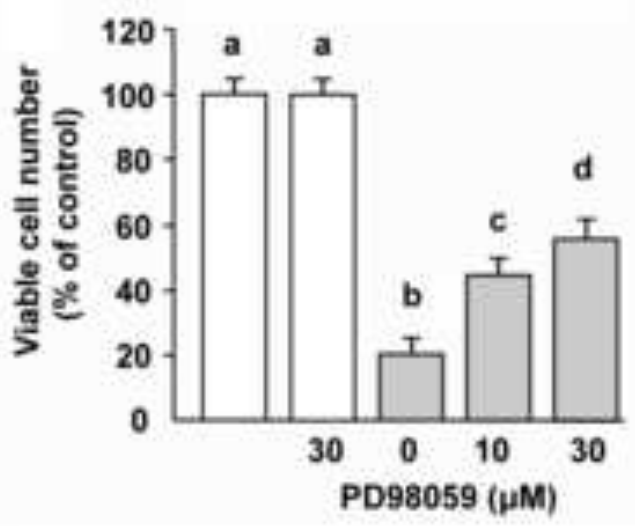

D
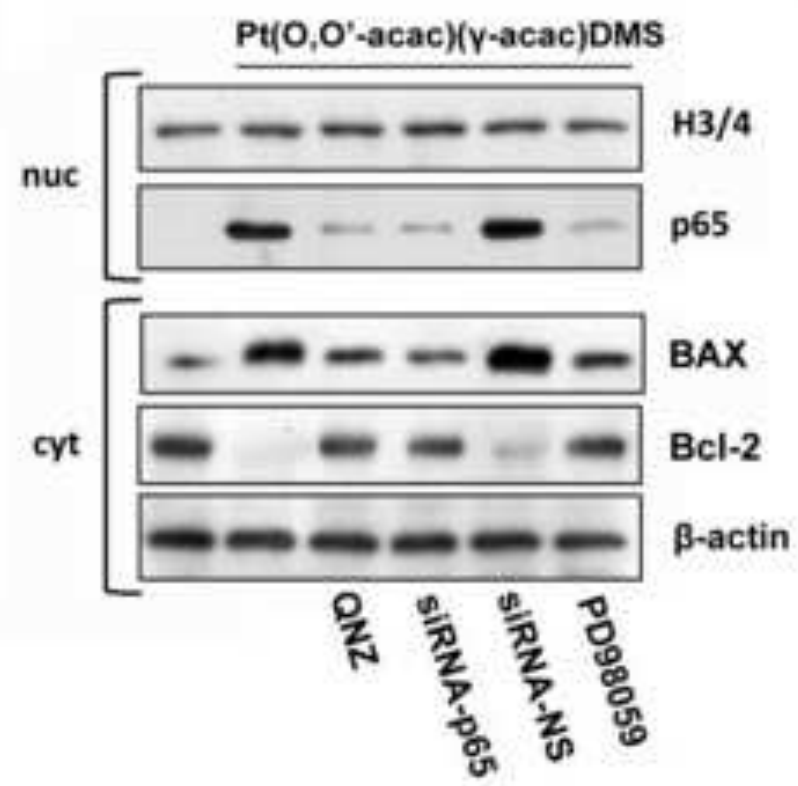

Fig 6 


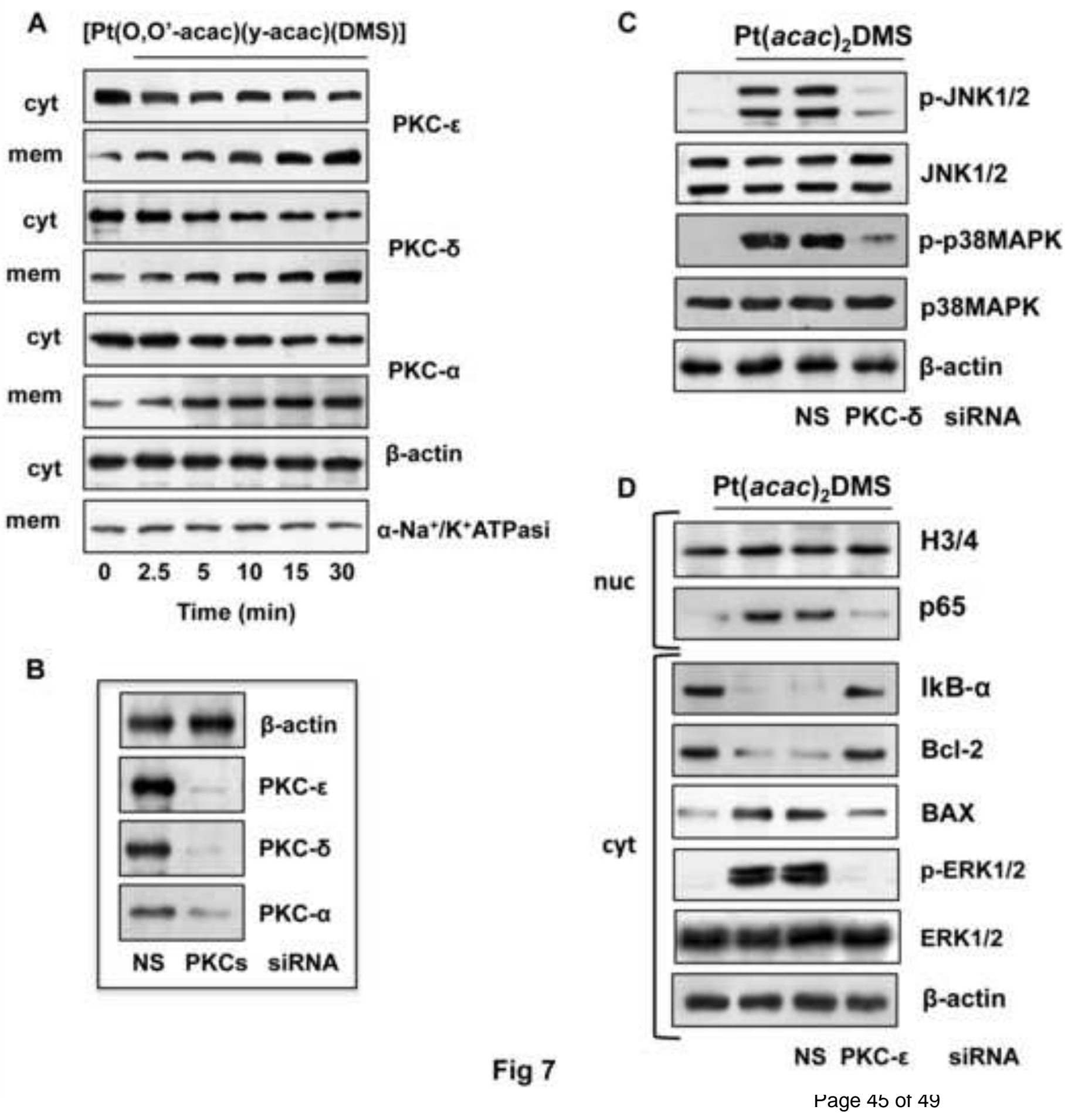



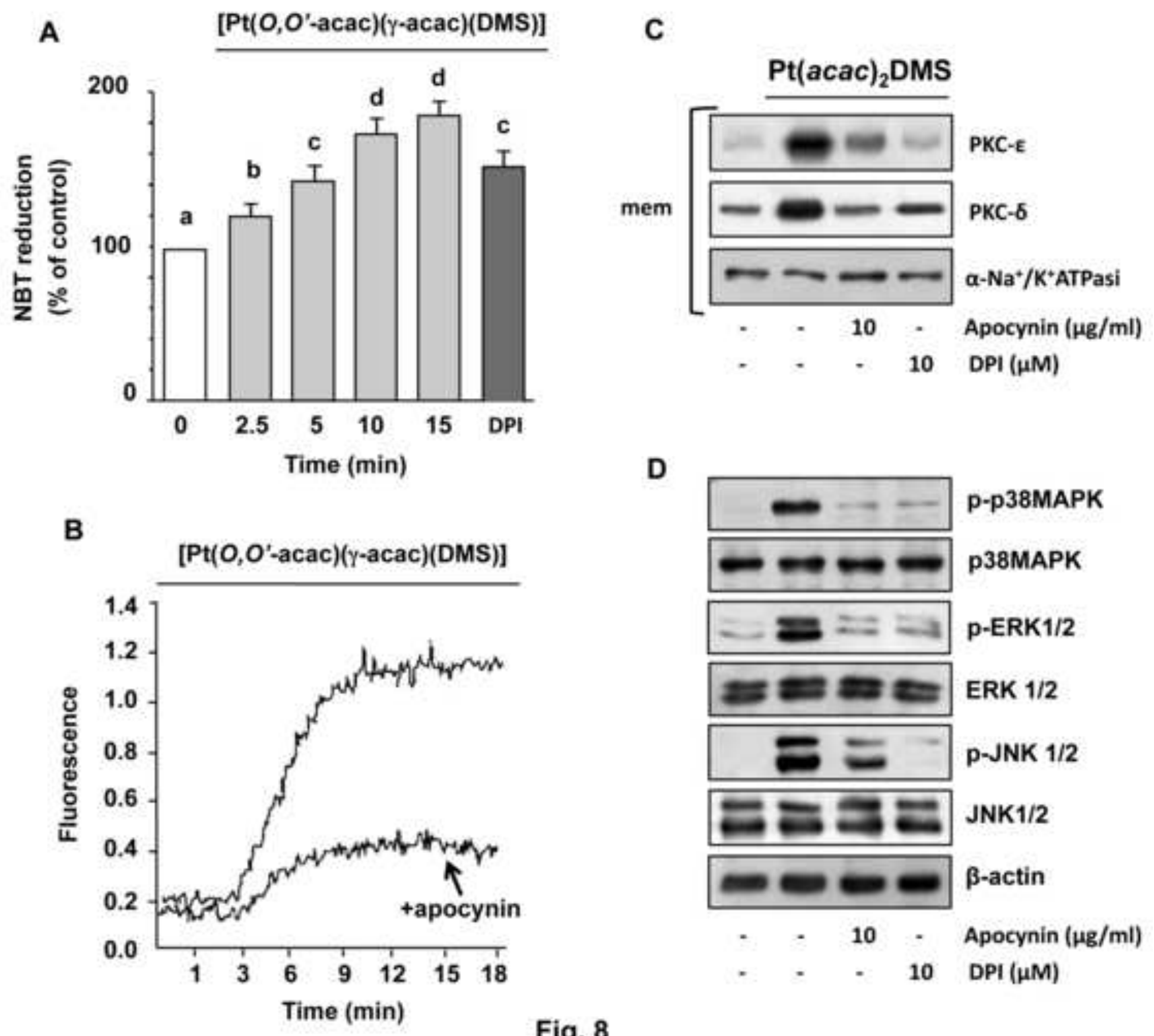

Fig. 8 


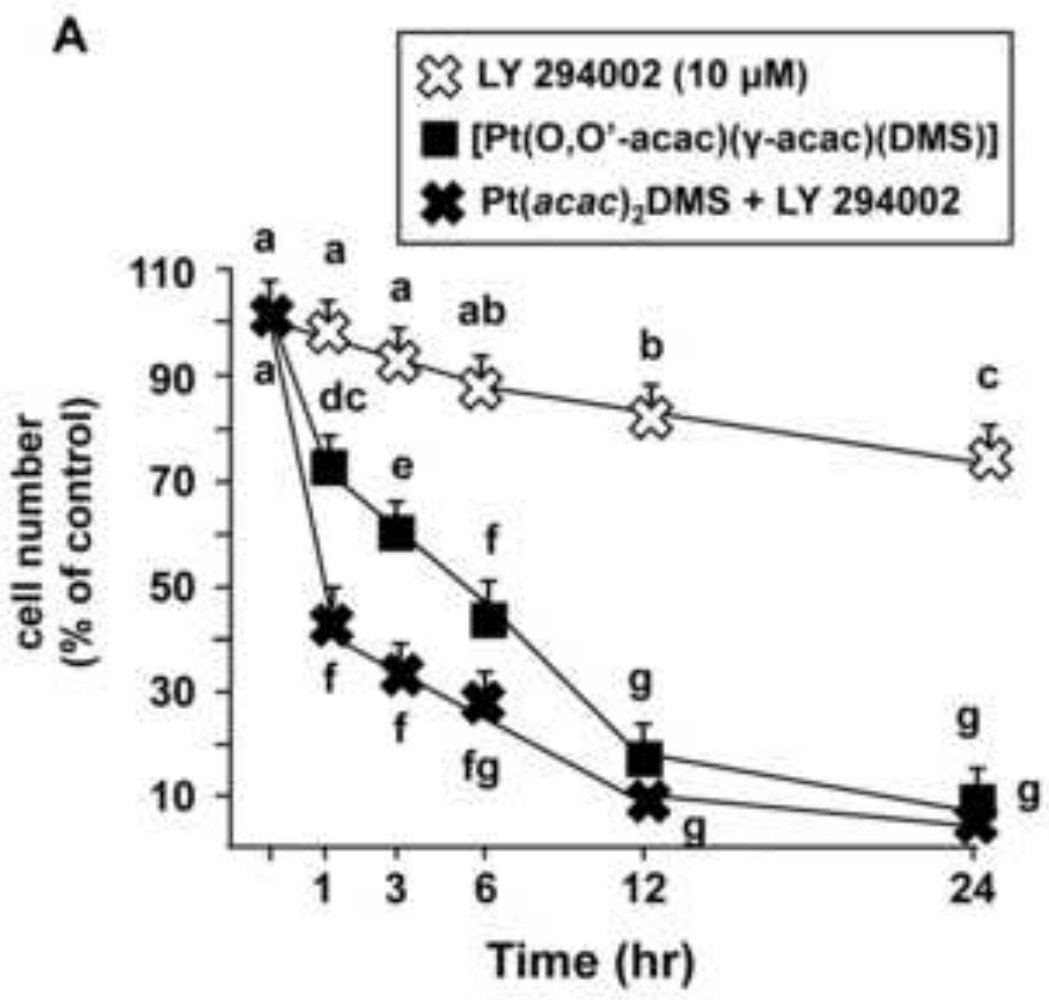

B

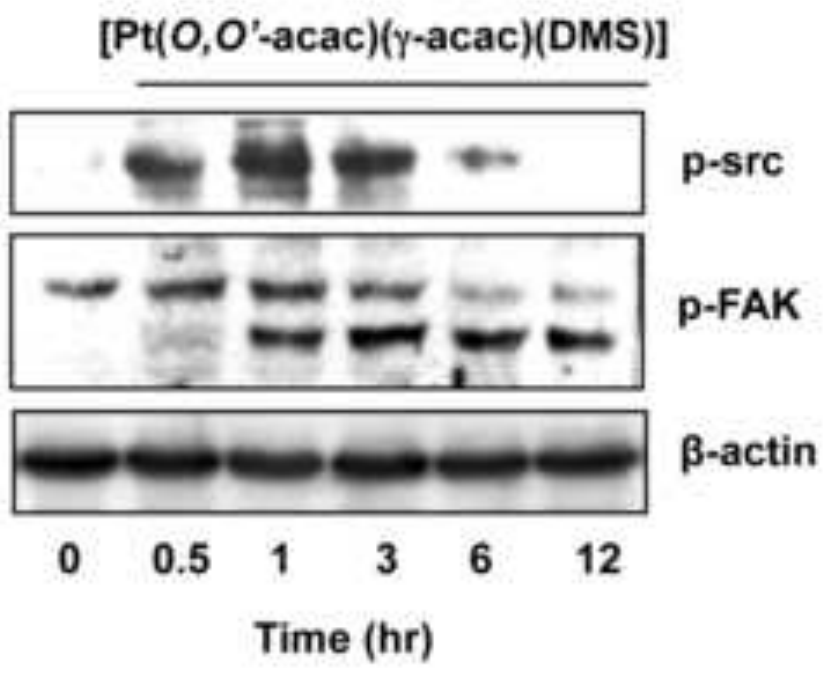

C [Pt(O,O'-acac)( $\gamma$-acac)(DMS $)]$
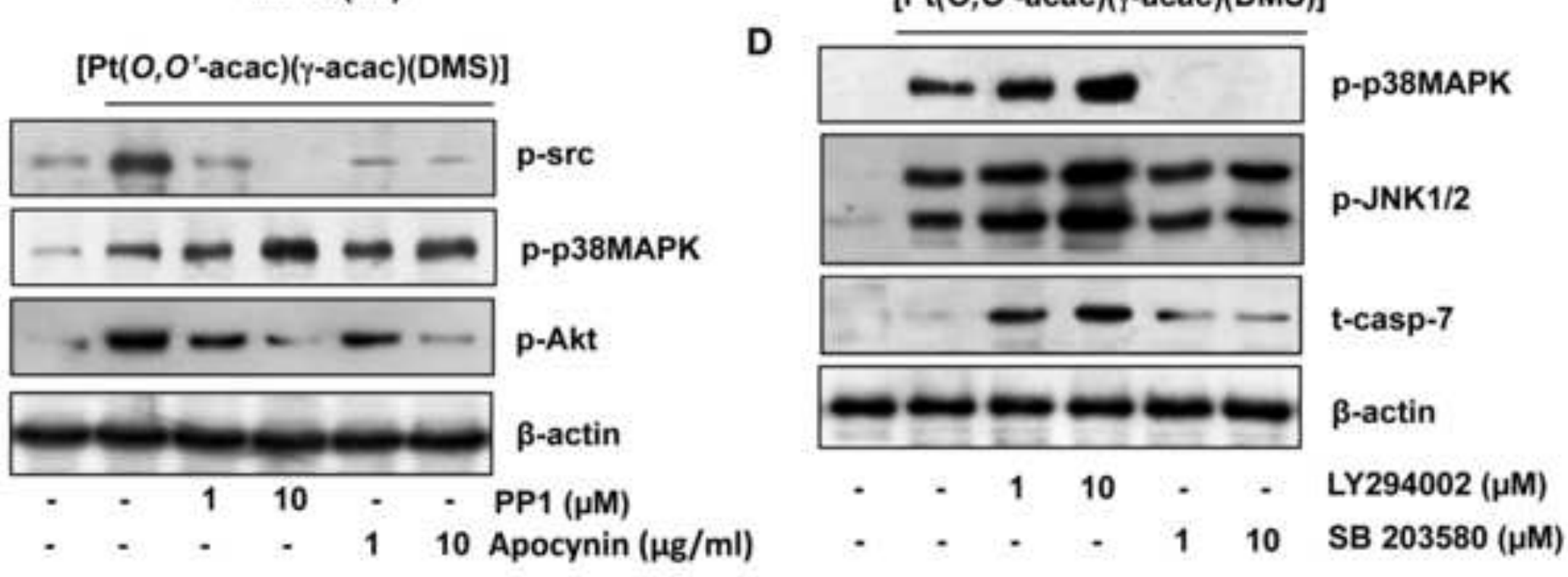

Fig 9 


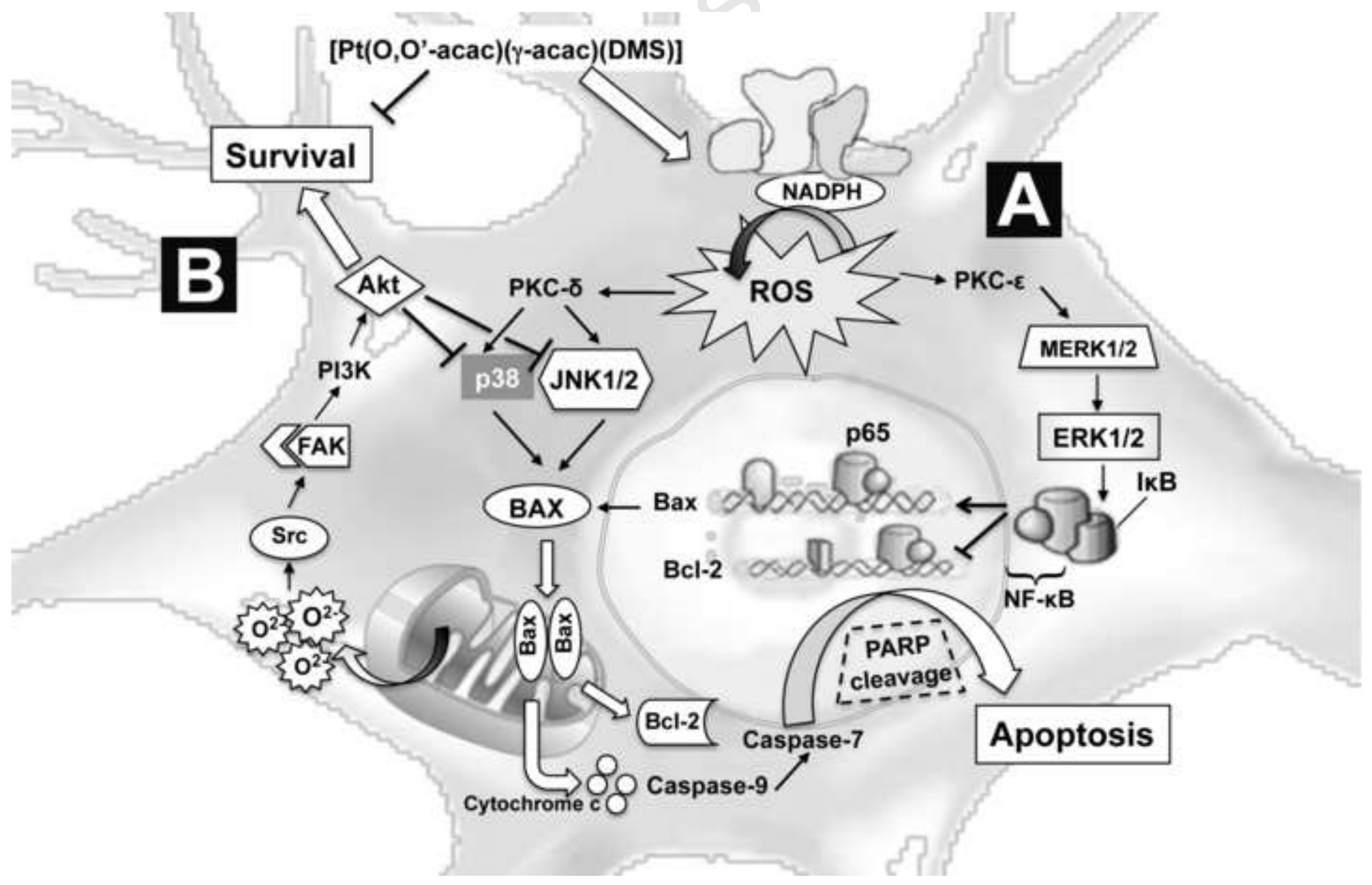




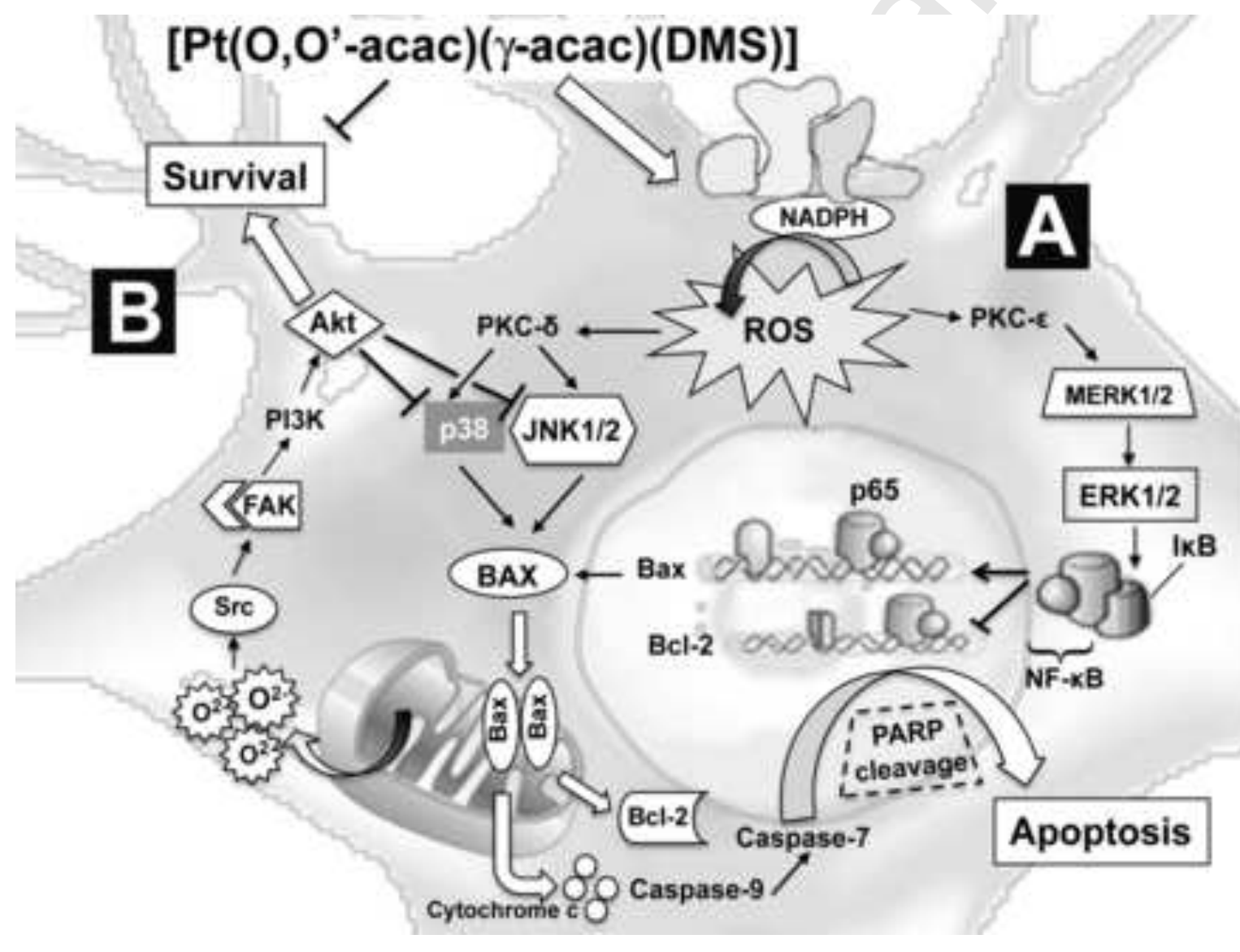

[Pt(O,O'-acac)( $\gamma$-acac)(DMS)] have a dual effect on human neuroblastoma cell line.

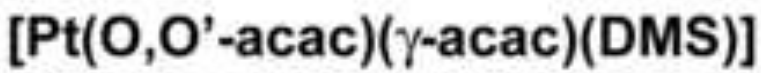
activates apoptotic mechanisms (A) and downregulates pro-survival pathways (B) starting from mitochondrial ROS generation 